\title{
Energy Efficiency Measures to Incorporate into Remodeling Projects
}

Christine Liaukus Building America Research Alliance (BARA)

December 2014

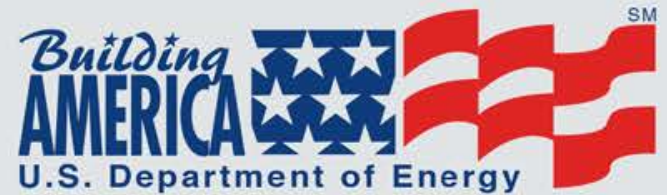




\section{NOTICE}

This report was prepared as an account of work sponsored by an agency of the United States government. Neither the United States government nor any agency thereof, nor any of their employees, subcontractors, or affiliated partners makes any warranty, express or implied, or assumes any legal liability or responsibility for the accuracy, completeness, or usefulness of any information, apparatus, product, or process disclosed, or represents that its use would not infringe privately owned rights. Reference herein to any specific commercial product, process, or service by trade name, trademark, manufacturer, or otherwise does not necessarily constitute or imply its endorsement, recommendation, or favoring by the United States government or any agency thereof. The views and opinions of authors expressed herein do not necessarily state or reflect those of the United States government or any agency thereof.

Available electronically at http://www.osti.gov/scitech

Available for a processing fee to U.S. Department of Energy and its contractors, in paper, from:

U.S. Department of Energy

Office of Scientific and Technical Information

P.O. Box 62

Oak Ridge, TN 37831-0062

phone: 865.576 .8401

fax: 865.576.5728

email: mailto:reports@adonis.osti.gov

Available for sale to the public, in paper, from:

U.S. Department of Commerce

National Technical Information Service

5285 Port Royal Road

Springfield, VA 22161

phone: 800.553 .6847

fax: 703.605.6900

email: orders@ntis.fedworld.gov

online ordering: http://www.ntis.gov/ordering.htm

Printed on paper containing at least $50 \%$ wastepaper, including $20 \%$ postconsumer waste 


\title{
Energy Efficiency Measures to Incorporate into Remodeling Projects
}

\author{
Prepared for:
}

The National Renewable Energy Laboratory

On behalf of the U.S. Department of Energy's Building America Program

Office of Energy Efficiency and Renewable Energy

15013 Denver West Parkway

Golden, CO 80401

NREL Contract No. DE-AC36-08GO28308

Prepared by:

C. Liaukus

Building Media and the Building America Retrofit Alliance (BARA)

12932 SE Kent-Kangley Road

Suite 529

Kent, WA 98030

NREL Technical Monitor: Stacey Rothgeb

Prepared under Subcontract No. KNDJ-0-40336-02

December 2014 
The work presented in this report does not represent performance of any product relative to regulated minimum efficiency requirements.

The laboratory and/or field sites used for this work are not certified rating test facilities. The conditions and methods under which products were characterized for this work differ from standard rating conditions, as described.

Because the methods and conditions differ, the reported results are not comparable to rated product performance and should only be used to estimate performance under the measured conditions. 


\section{Contents}

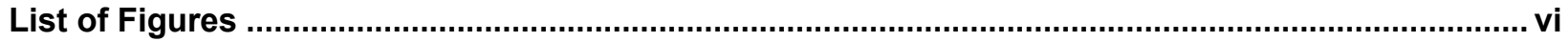

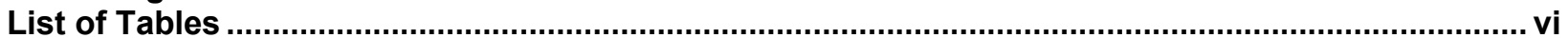

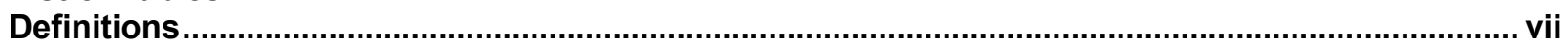

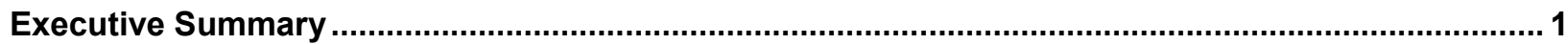

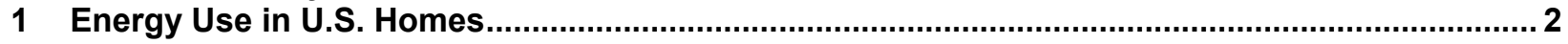

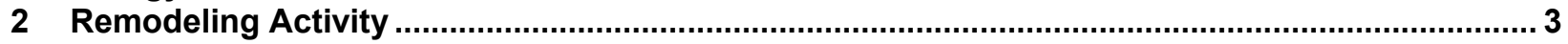

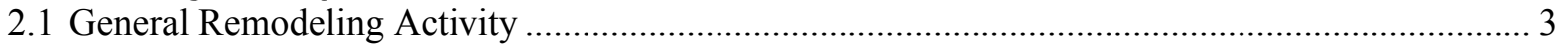

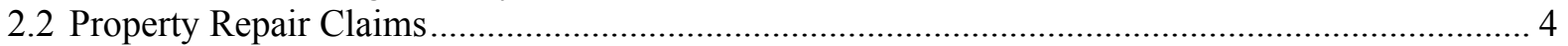

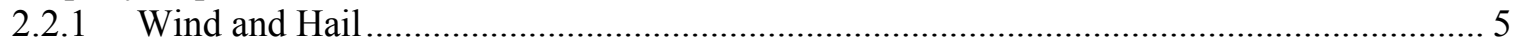

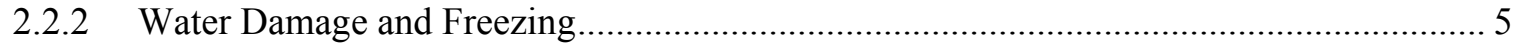

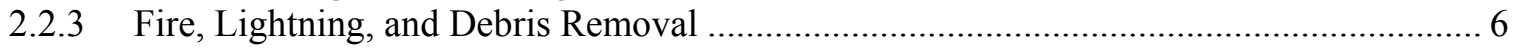

3 Incorporating Energy Efficiency Measures With Remodeling and Repair Activities .................. 7

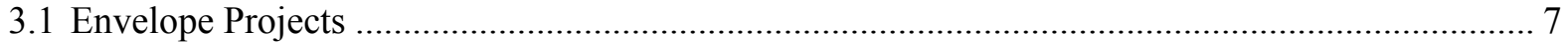

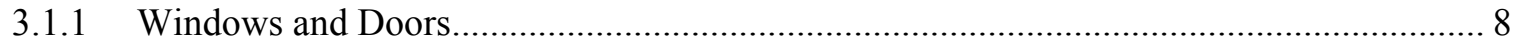

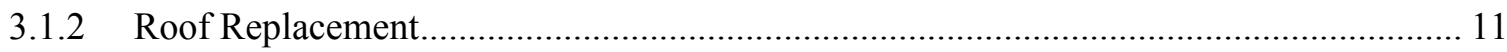

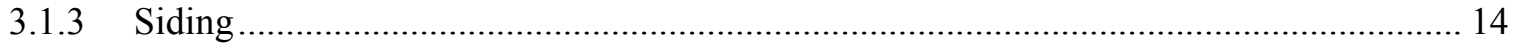

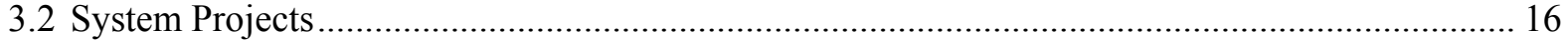

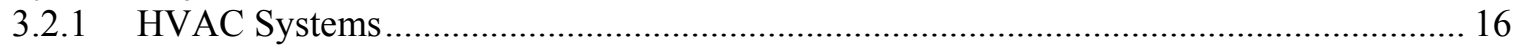

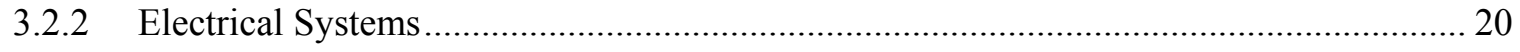

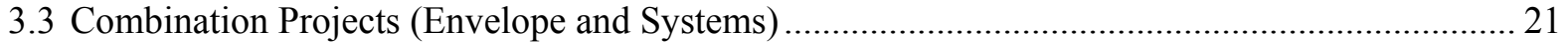

3.3.1 Room Additions Other Than Kitchens, Bedrooms, and Bathrooms ............................... 22

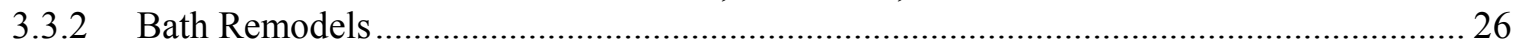

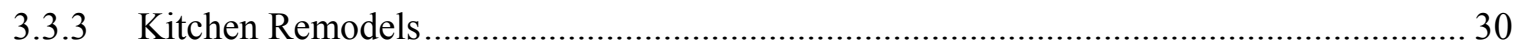

4 Summary of Remodeling Projects and Potential Energy Efficiency Measures ........................33

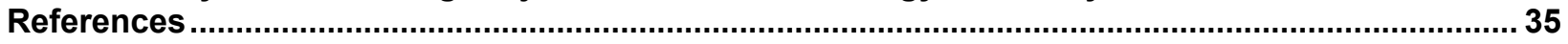




\section{List of Figures}

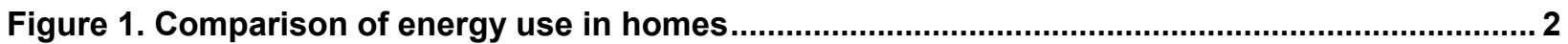

Figure 2. ENERGY STAR windows climate zone map............................................................... 8

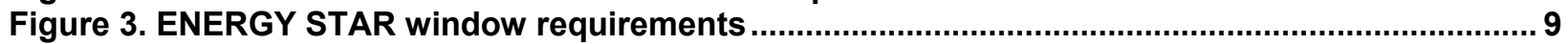

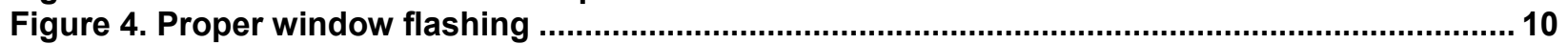

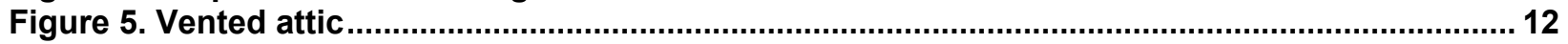

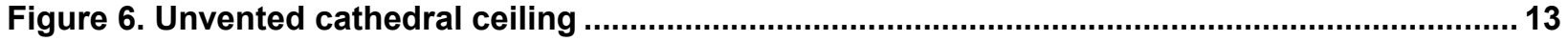

Figure 7. Vented cathedral ceiling ............................................................................................. 13

Figure 8. Window flashing 1: windows need to be properly flashed to avoid air leakage and water

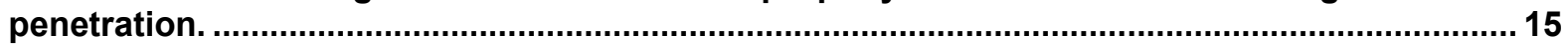

Figure 9. Air barrier 1: all seams need to be taped so the air barrier is continuous........................15

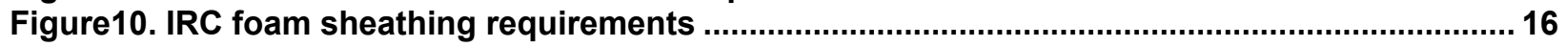

Figure 11. Basic decisions for replacing your heating system .................................................... 17

Figure 12. Basic decisions for replacing your cooling system ...................................................... 18

Figure 13. System guidance from DOE Best Practices Guide for Residential HVAC Retrofits ........ 19

Figure 14. Use of air gap membrane and insulation as a "wet slab" retrofit .....................................22

Figure 15. Example Building America Best Practice Series............................................................. 23

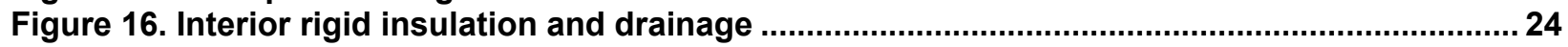

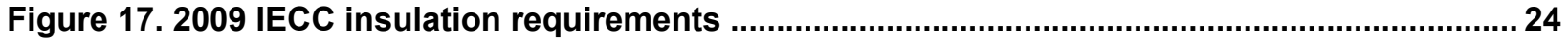

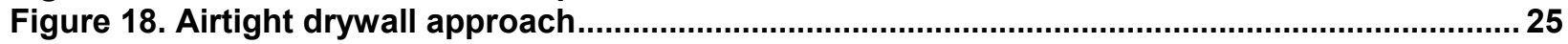

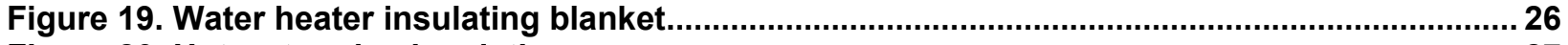

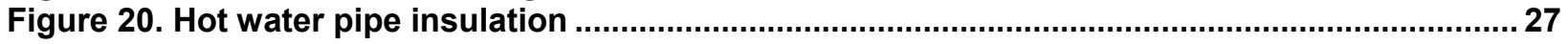

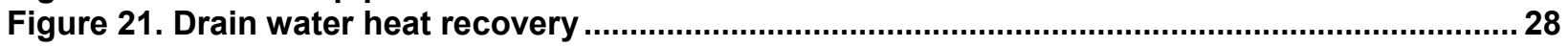

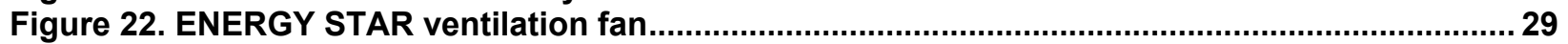

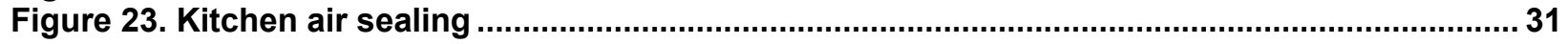

Unless otherwise noted, all figures were created by the BARA team.

\section{List of Tables}

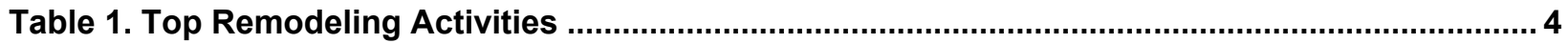

Table 2. Typical Causes of Damage and the Associated Repairs for Homeowner Claims ............... 5

Table 3. EEMs To Consider When Replacing Windows ................................................................ 10

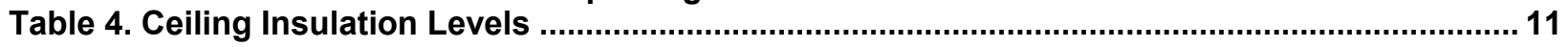

Table 5. Minimum R-Value for Rigid Foam on Top of Roof Sheathing ............................................. 12

Table 6. EEMs To Consider When Replacing the Roof ............................................................... 14

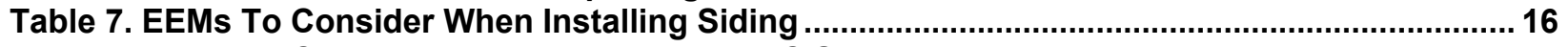

Table 8. EEMs To Consider When Replacing HVAC Systems......................................................... 19

Table 9. EEMs To Consider When Installing Electrical Systems ................................................ 21

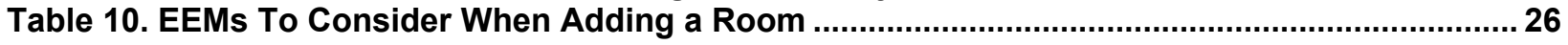

Table 11. EEMs To Consider When Remodeling a Bathroom .............................................................. 30

Table 12. EEMs To Consider When Remodeling a Kitchen .......................................................... 32

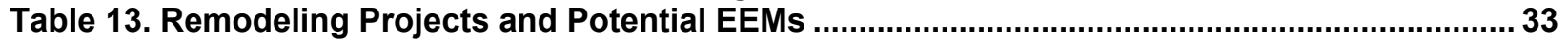

Unless otherwise noted, all tables were created by the BARA team. 


\section{Definitions}

$\begin{array}{ll}\text { BARA } & \text { Building America Retrofit Alliance } \\ \text { CFL } & \text { Compact Fluorescent Lamp } \\ \text { DOE } & \text { U.S. Department of Energy } \\ \text { EEM } & \text { Energy Efficiency Measure } \\ \text { IBHS } & \text { Institute for Business and Home Safety } \\ \text { IECC } & \text { International Energy Conservation Code } \\ \text { IRC } & \text { International Residential Code } \\ \text { HVAC } & \text { Heating, Ventilation, and Air Conditioning } \\ \text { LED } & \text { Light-Emitting Diode } \\ \text { MEL } & \text { Miscellaneous Electric Load }\end{array}$




\section{Executive Summary}

Energy improvements in a home are often approached as one concerted effort, beginning with a simple walk-through assessment or more in-depth energy audit and followed by the installation of recommended energy measures. While this approach allows for systems thinking to guide the efforts, comprehensive energy improvements of this nature are undertaken by a relatively small number of the households in our nation compared to more piecemeal remodeling efforts. Even when programs like the Weatherization Assistance Program and Home Performance with ENERGY STAR are considered, homes that have had a comprehensive energy makeover still represent a small fraction of the 111.1 million households.

In this report, the U.S Department of Energy Building America Retrofit Alliance research team looks at the improvement of a home's energy performance in an opportunistic way: it examines what can be done to incorporate energy efficiency measures into general remodeling work and home repair projects. This allows for the possibility for people who would not normally pursue energy efficiency but will remodel their kitchen or re-side their home to improve their home's performance at the same time. There are challenges to this approach, not the least of which being that the work will take place over time in potentially many separate projects. The opportunity to improve a home's energy efficiency at one time expands or contracts with the scope of the remodel. As such, guidance on how to do each piece thoughtfully and with consideration for potential future projects, is critical. 


\section{Energy Use in U.S. Homes}

Energy usage in U.S. homes has shifted in the last 27 years. Space heating used to be a larger piece of the energy pie, consuming $66 \%$ of total household energy use in 1978 versus $41 \%$ in 2005, and a larger absolute number, 6.96 quadrillion Btu versus 4.3 quadrillion Btu. This drop is more significant than it appears as the number of occupied households increased from 76.6 million units in 1978 to 111.1 million by 2005. The dramatic drop in energy use is attributed to improvements in heating equipment efficiency, window design, and insulation and air sealing in homes. In addition, a portion of the reduction is a result of an increase in the number of households in warmer climates. Counter to those reductions in space heating use, electricity use by appliances and electronics has increased from 1.77 quadrillion Btu to 3.25 over the same period (U. S. Energy Information Administration, 2011).
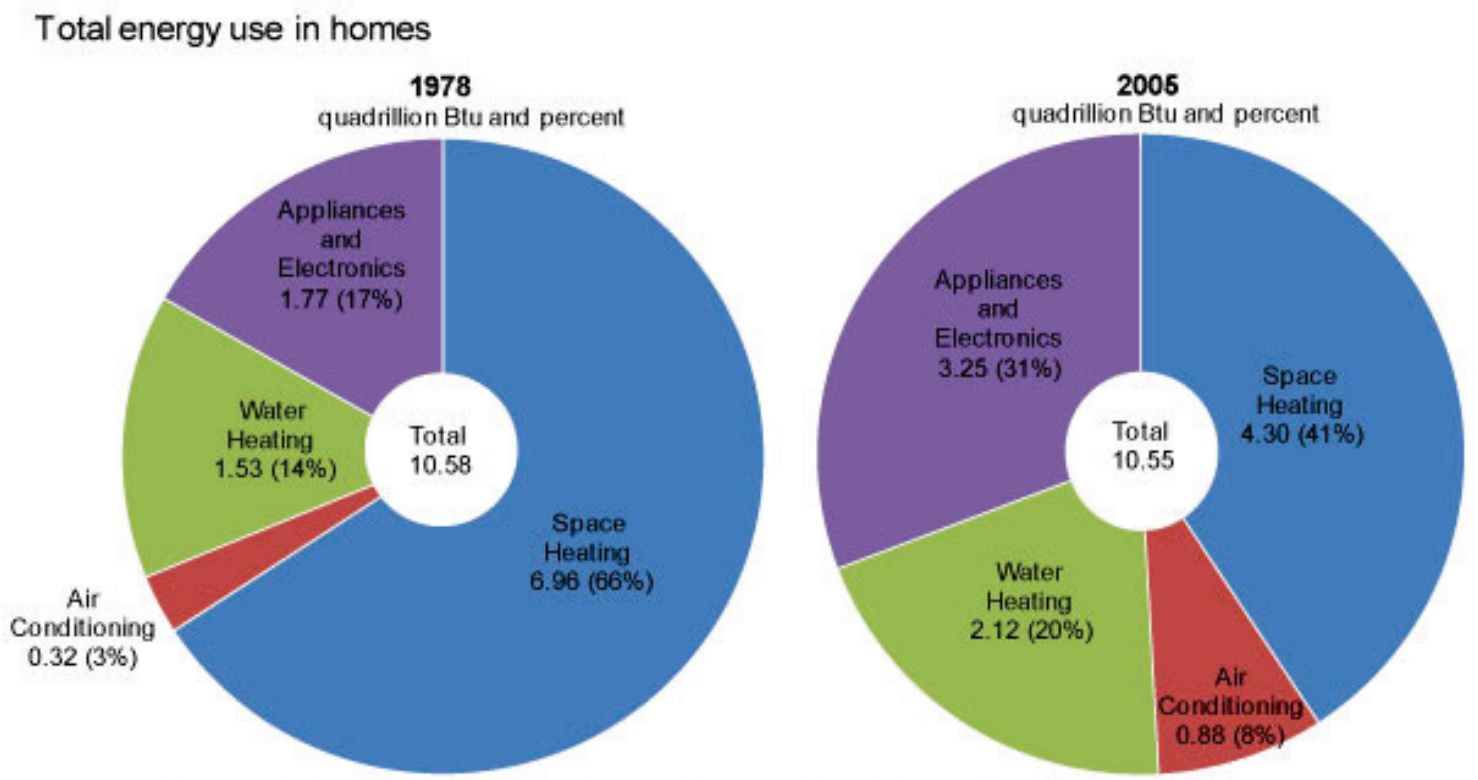

Source: U.S. Energy Information Administration, 1978 and 2005 Residential Energy Consumption Survey

Figure 1. Comparison of energy use in homes

(EIA 2005)

Although the drop in space heating energy use is promising, much more can be done to improve the envelopes of existing homes. Data have shown that most existing homes could easily be tightened by $25 \%$ and still not require mechanical ventilation for acceptable indoor air quality (Sherman, Air Tightness: Experiences from US, 2010). Beyond infiltration, homes built prior to 1980 often have inadequate wall insulation (Roberts \& Stephenson, 2010). Homes built before 1980 account for $68.7 \%$ of the U.S. housing stock (U. S. Census Bureau, 2011). The dramatic increase in electric loads calls for attention as well, since they have increased $80 \%$ since 1978 and continue to rise. 


\section{Remodeling Activity}

This report looks at two types of remodeling activity: general remodeling and repair work.

\subsection{General Remodeling Activity}

According to a study by the Harvard University Joint Center for Housing Studies (Joint Center for Housing Studies of Harvard University, 2011), the top 15 remodeling projects within owneroccupied U.S. homes in 2009 (in order of frequency) included:

- Flooring/paneling/ceiling

- Appliances/major equipment

- Windows and doors

- Plumbing fixtures

- Roofing replacement

- Heating, ventilation, and air conditioning (HVAC)

- Electrical systems

- Insulation

- Plumbing/pipes

- Minor bath remodel

- Addition other $^{1}$

- Siding

- Minor kitchen remodel

- Major bath remodel

- Disaster repair.

Table 1 shows remodeling activities that allow for energy efficiency measures (EEMs) beyond one item. ${ }^{2}$

\footnotetext{
${ }^{1}$ This does not include kitchens, bathrooms, or bedrooms. It includes created finished recreation room from unfinished space, created other finished inside room from unfinished space, added other inside room onto home, and other room created through structural changes.

${ }^{2}$ For example, plumbing fixtures should be selected that are water efficient and they should be installed properly; beyond that, the scope of the remodel is too small for other energy opportunities.
} 
Table 1. Top Remodeling Activities

(Joint Center for Housing Studies of Harvard University, 2011)

\begin{tabular}{|c|c|c|}
\hline Project & $\begin{array}{c}\text { Homeowners Reporting } \\
\text { Projects }(1,000 s)\end{array}$ & Average Expenditure \\
\hline Windows/Doors & 4,370 & $\$ 2,203$ \\
\hline Roofing & 3,369 & $\$ 4,989$ \\
\hline HVAC & 3,314 & $\$ 3,969$ \\
\hline Electrical Systems & 2,365 & $\$ 1,031$ \\
\hline Minor Bath Remodel & 1,359 & $\$ 1,383$ \\
\hline Disaster Repair ${ }^{3}$ & 1,599 & $\$ 10,508$ \\
\hline Addition Other ${ }^{1}$ & 1,257 & $\$ 13,462$ \\
\hline Siding & 1,136 & $\$ 4,266$ \\
\hline Minor Kitchen Remodel & 1,134 & $\$ 2,785$ \\
\hline Major Bath Remodel & 1,106 & $\$ 9,145$ \\
\hline Major Kitchen Remodel & 834 & $\$ 20,556$ \\
\hline
\end{tabular}

The average expenditure for each project type shown in Table 1 can be helpful when considering the incremental cost of including energy efficiency measures (EEMs). While this report does not include an economic analysis of the proposed measures, a general sense of outlaid dollars can help guide the suggestions for incorporating energy efficiency.

\subsection{Property Repair Claims}

Property repair is another broad category of remodeling activity. As shown in Table 2, the most common homeowner claims that affect the physical building are wind and hail, water damage and freezing, all other property damage, and fire, lightning, and debris removal. Casualty claims are shown in this table, but are not within the scope of this report. In the American Housing Survey, disaster repair accounts for 1,599,000 homeowner-reported projects (U.S. Census, 2011). A more specific breakout of what these projects included is not contained in the American Housing Survey microdata. The survey does ask about repair work but it is not isolated from disaster repair. So, a respondent may say that they replaced their roof and that they had repairs as a result of a disaster, which can allow the repair to be counted twice. After communicating with the Institute for Building and Home Safety (IBHS), ISO Verisk, and other insurance industry members, it was found that specific repairs done as a result of homeowner insurance claims are not tracked for the country and insurance industry overall. Individual insurance companies that do have these data consider them proprietary.

In the absence of national statistically significant data on the most common property repairs made using homeowner insurance claim funds, the Building America Research Alliance (BARA) team held interviews with eight property repair contractors and three representatives of the insurance industry: staff members at IBHS, ISO, and a Prudential subsidiary that writes homeowner's insurance. State $\mathrm{Farm}^{4}$ was not responsive to inquiries. These interviews and

\footnotetext{
${ }^{3}$ Disaster repair may include roofing, siding, doors, and windows as the American Housing Survey allows homeowners to include projects in more than one category.

${ }^{4}$ State Farm is the largest home insurance company in the United States (Spelling, 2011).
} 
communications informed Table 2. Contractors that specialized in homeowner insurance claim repair work were asked what their most frequent job types are and what those projects entail. Insurance agents were asked what is typically covered for different claims. In addition, the program requirements for IBHS's Fortified Home Program were reviewed to see which areas of the home are more susceptible to damage and therefore might be repaired more frequently as a result of an insurance claim. The Fortified Home Program has requirements for specific types of disasters.

Table 2. Typical Causes of Damage and the Associated Repairs for Homeowner Claims

\begin{tabular}{c|c|c|c}
\hline \multirow{2}{*}{ Repairs } & \multicolumn{3}{|c}{ Causes of Damage } \\
\cline { 2 - 4 } Roofing & Repair affected slope & $\begin{array}{c}\text { Water Damage and } \\
\text { Freezing }\end{array}$ & $\begin{array}{c}\text { Fire, Lightning, and } \\
\text { Debris Removal }\end{array}$ \\
\hline repair affected slope & $\begin{array}{c}\text { Patch or replace } \\
\text { entire façade }\end{array}$ & Not applicable & Repair affected slope \\
Walling & Not applicable & $\begin{array}{c}\text { Patch or replace entire } \\
\text { façade } \\
\text { and insulation as } \\
\text { appropriate }\end{array}$ & $\begin{array}{c}\text { As needed in affected } \\
\text { rooms or rooms to be } \\
\text { gutted }\end{array}$ \\
& $\begin{array}{c}\text { Window and door } \\
\text { replacement }\end{array}$ & Mold remediation & $\begin{array}{c}\text { Smoke damage } \\
\text { remediation }\end{array}$ \\
\hline
\end{tabular}

\subsubsection{Wind and Hail}

According to the contractor interviews, wind and hail often affect the roof and siding of a home. Except for extreme situations, roofs typically do not require complete replacement but one or more slopes may be affected. Often, if an insurance claim will cover one slope of a roof, the homeowner will decide to pay the additional cost to replace the whole roof as matching shingles in the old and new areas is difficult (Hall, 2011). Siding can be repaired in the immediate area of the damage, as it can be easier to match than roofing shingles.

The avoidance of wind and hail damage is the focus of the IBHS Fortified Home Program Hurricane Resistance Designation (Rem Brown, 2011). This program provides home retrofit requirements to achieve better disaster protection in existing homes. For this program, existing homes are inspected with a focus on specific areas "which building science research has identified as the highest sources of loss during hurricanes." The program focuses on the roof structure and covering; attic ventilation; window, entry door, and garage door openings; gableend framing; the connection of auxiliary structures; and continuous load path connections (Institute for Business and Home Safety, 2011). Placing the roof as the top priority for inspection and modification is logical and corroborates with the contractors' experiences that roof repair and/or replacement is often encountered as a result of wind and hail damage. Windows and doors, which are often replaced as a result of wind and hail damage, are also part of this program's focus.

\subsubsection{Water Damage and Freezing}

Water damage and freezing will vary in the way they affect the home depending on how quickly the problem is discovered and addressed. A burst pipe discovered and repaired immediately may 
result in a few thousand dollars' worth of damage. If left for 6 hours, the costs can double or triple (Hall, 2011). Water damage from an interior source, such as a burst pipe, obviously causes greater damage when on an upper floor rather than in a basement. As more homes have finished basements, even in this location there can be extensive damage. If the basement is unfinished, flooding from an internal water source can still ruin mechanical equipment and require that it be replaced. Failed water heaters are often the culprit for internal source water damage. When that is the case, the repairs needed as a result of the water damage are typically covered by insurance, but replacement of the water heater is not covered (Latiri, 2011). Water damage in finished spaces will often require the replacement of sheetrock, insulation, and, at times, the actual framing of ceilings and walls. Floors can also require repair and/or replacement. Mold is also a concern and may require finish-flooring replacement, specifically of carpeting. Some insurance agents find that if mold in carpeting cannot be remediated within 72 hours, the carpeting needs to be replaced (Latiri, 2011).

\subsubsection{Fire, Lightning, and Debris Removal}

Fire damage often requires gutting the space in which the fire took place. Cooking fires are the top cause of home fires in the United States and 94\% of home cooking fires between 2005 and 2009 started in the kitchen (National Fire Protection Association, 2011). In these instances, fires typically spread through the room of origin ( $43 \%$ of the time) or affected the entire building of origin $(46 \%)$, be it a home or apartment building. As such, property repair because of fire can often result in major kitchen remodels or even more extensive remodeling. Kitchen remodels as a result of stove fires were one of the top homeowner insurance claim projects done by one of the contractors interviewed for this report (Hammer, 2011). 


\section{Incorporating Energy Efficiency Measures With Remodeling and Repair Activities}

Exploring opportunities to improve the energy efficiency of homes that are being remodeled for other reasons is the focus of this report. The suggested actions to be added to remodeling activities in this report are not new, and much of the information has been culled from earlier Building America publications and other sources. What is new is the strategy to join EEMs with other remodeling activities.

General remodeling activity and property repair have much overlap. Some repair projects are unique to disasters and system failures, such as mold remediation and smoke damage. Often other repairs needed as a result of disaster are similar to those done as a general remodel, but they may have an increased scope and are typically not planned for, such as planning for a new roof versus having a tree fall on the roof. Both result in a new roof, but under very different circumstances. The roof to be repaired will create more of a challenge for EEMs to be incorporated. As such, the incorporation of EEMs into repair projects may be more challenging overall.

For this report, the initial list of remodeling activity has been organized into three major groups:

Envelope projects:

- Windows and doors

- Roof replacement

- Siding.

Systems projects:

- HVAC systems

- Electrical systems.

Combination projects (envelope and systems):

- Room additions other than kitchens, bedrooms, and bathrooms

- Bath remodels

- Kitchen remodels.

All of the repair activity falls within the defined remodeling projects except for mold remediation and smoke damage remediation.

\subsection{Envelope Projects}

Programs to improve the energy efficiency of existing U.S. homes, such as Home Performance with ENERGY STAR (and the Weatherization Assistance Program, focus mainly on the building envelope. At the envelope, there is the opportunity to air seal and insulate. The degree to which the overall building envelope can be affected when only a portion of it is being remodeled 
depends on the size of the project. Yet, if improving the efficiency of the home is considered as being done over time, then optimizing the energy efficiency of each room or area as it is worked on may ultimately result in an appreciably more efficient home.

\subsubsection{Windows and Doors}

If windows are to be replaced for durability or aesthetic reasons, choosing more energy-efficient windows can be beneficial. It is not cost effective to replace windows solely for energy savings. An analysis of homes in the Home Performance with ENERGY STAR program in New York State in which the windows were replaced as the only EEM showed that the savings were very small. Additionally, the Energy Trust of Oregon also found that window replacement results in savings that did not justify the expense of the measure (Sipe, 2011). Savings are higher if the windows being replaced are single pane or jalousie, but it is still not cost effective. For cooling, windows can account for up to $60 \%$ of the cooling load, so the savings improves, yet, replacing windows solely for energy savings is again not cost effective (Blasnik, 2011).

When windows are being replaced anyway, paying the incremental cost for better performing windows is advisable. The ENERGY STAR ${ }^{\circledR}$ program has specific window recommendations based on climate. See the climate zones in Figure 2 and the window performance criteria for each climate zone in Figure 3.

Proper installation of the window is critical to avoid air leakage and moisture issues. The proper sealing and flashing of windows, both with and without existing house wrap, is shown in Figure 4, from the Building America Best Practices series of publications (PNNL and ORNL, 2006).

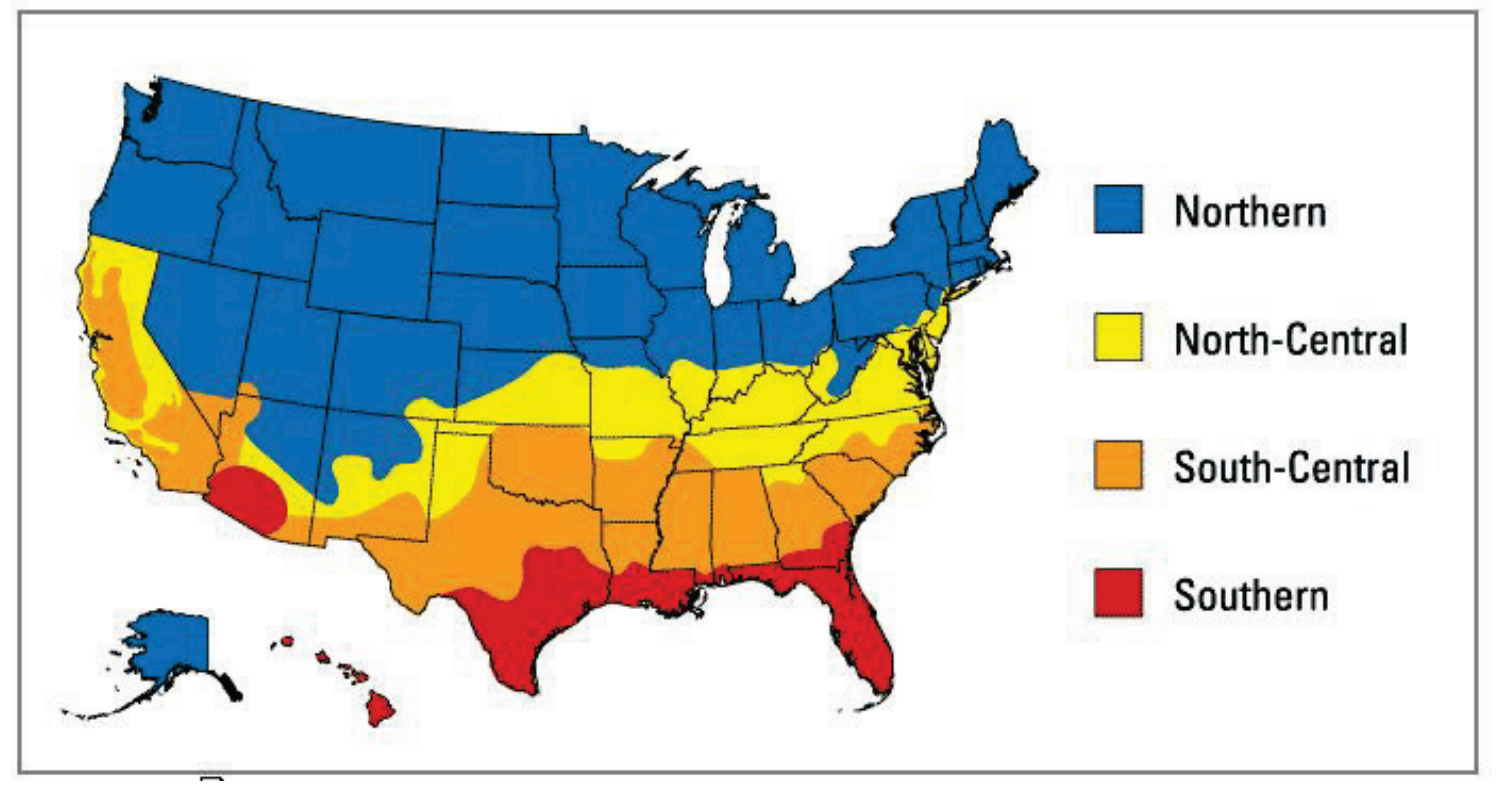

Figure 2. ENERGY STAR windows climate zone map

(ENERGY STAR, 2010) 


\begin{tabular}{|c|c|c|c|}
\hline \multirow[b]{2}{*}{ Climate Zone } & \multicolumn{2}{|c|}{ Windows } & \\
\hline & U-Factor ${ }^{1}$ & $\mathrm{SHGC}^{2}$ & \\
\hline \multirow[t]{3}{*}{ Northern } & $\leq 0.30$ & Any & Prescriptive \\
\hline & $=0.31$ & 20.35 & Equivalent \\
\hline & $=0.32$ & $\geq 0.40$ & Performance \\
\hline $\begin{array}{l}\text { North- } \\
\text { Central }\end{array}$ & $\leq 0.32$ & $\leq 0.40$ & \\
\hline $\begin{array}{l}\text { South- } \\
\text { Central }\end{array}$ & $\leq 0.35$ & $\leq 0.30$ & \\
\hline Southern & $\leq 0.60$ & $\leq 0.27$ & \\
\hline
\end{tabular}

Figure 3. ENERGY STAR window requirements

(ENERGY STAR, 2010) 


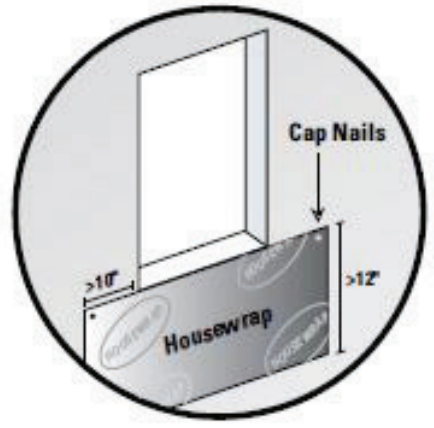

- Apply at least a 12 -inch flap, or apron, of building paper or housewrap just below the windows sill.

If the window sill is close to the sill plate, the apron can extend all the way to the sill plate.

- The apron should extend at least 10 inches past the sides of the window opening, or to the first stud in open wall construction.

- Attach only the apron's top edge with cap nails.

STEP 2 - SILFLASHING

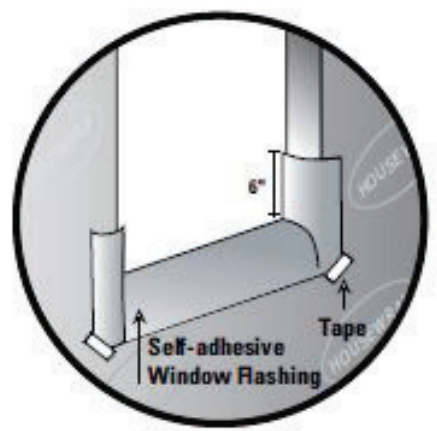

Install self-adhesive flashing to the sill, ensuring that flashing extends up jambs at least 6 inches.

- One commercial product comes with two removable strips over the adhesive. Remove the first strip to expose half the adhesive and apply this area to the sill. Begin pressing in the middle of the sill and work towards the sides. Remove the second strip to expose the adhesive that will be used to apply the flashing below the window to the outside wall.

- Tape down the bottom corners of the flashing

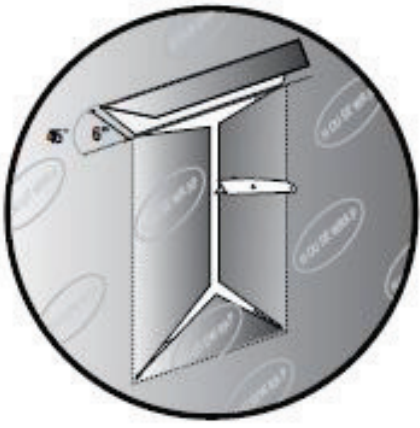

- Cut the housewrap covering the rough opening in the shape of a modified "Y."

- Fold the side and botrom flaps into the window opening and secure.

- Above the window opening, cut a head flap and flip up to expose shearhing, and loosely tape in place out of the way.

STEP 3 - JAMB CAULKING

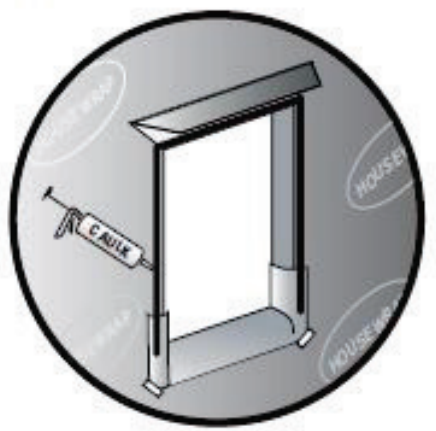

- Caulk the outside edges of the head and side jambs

Do not caulk across the sill

- Install the window using corrosion-resistant nails and following manufacturer's specifications.

Figure 4. Proper window flashing

(PNNL and ORNL 2006)

Table 3 shows a summary of EEMs to be considered when replacing windows.

Table 3. EEMs To Consider When Replacing Windows

Windows

Do not replace if only pursuing energy savings Specify ENERGY STAR windows or better, see Figure 3 Incorporate proper air and moisture sealing strategies, see Figure 4 


\subsubsection{Roof Replacement}

When retrofitting roofs, there are several opportunities available to improve energy efficiency, comfort, and building durability. Comfort can be improved by reducing air leakage and increasing insulation. In turn, these can improve building durability and reduce heating and cooling loads. Roofing material selection can also impact heating and cooling loads.

\subsubsection{Air Sealing}

Air sealing should be done as part of any attic or ceiling retrofit before any new or additional insulating is done. Air leakage through ceilings can be a major source of attic moisture and heat loss in homes. Moisture damage to roof sheathing, framing members, and finished ceilings can result from some combination of air leakage, insulation, and ventilation problems (Toolbase 2010; Lstiburek 2012).

If the roof is above an unconditioned attic, the air sealing occurs at the ceiling plane and adequate soffit and ridge, mushroom, or gable vents should be accommodated. The goal should be to allow the entire underside of the roof deck to be ventilated (Green Building Advisor, 2011).

\subsubsection{Insulation}

Insulation at the ceiling plane is the easiest to install or add to when there is a flat ceiling with an accessible attic above. Meeting or exceeding the levels in the 2009 International Residential Code (IRC) (see Table 4) is less often compromised by inadequate space. This does become an issue when flooring is put over the ceiling joists and/or when the roof slope reduces the space for insulation over the exterior walls. See Figure 5 for an insulated attic example.

Table 4. Ceiling Insulation Levels

(2009 IRC)

\begin{tabular}{c|c}
\hline Climate Zone & Ceiling R-Value \\
\hline $\mathbf{1 , 2}$, and $\mathbf{3}$ & 30 \\
$\mathbf{4}$ and $\mathbf{5}$ & 38 \\
$\mathbf{6 , 7}$, and $\mathbf{8}$ & 49 \\
\hline
\end{tabular}

In the case of an unvented cathedral ceiling, one way to add R-value to the roof is to include layers of rigid foam sheathing either on top of the roof deck, as shown in Figure 6, or between the rafters on the underside of the deck. Both methods increase R-value, and, when done on top of the roof deck, provide a thermal break to the entire assembly. When installing rigid insulation on top of the roof sheathing, minimum R-values are required by the 2009 IRC, see Table 5 . 


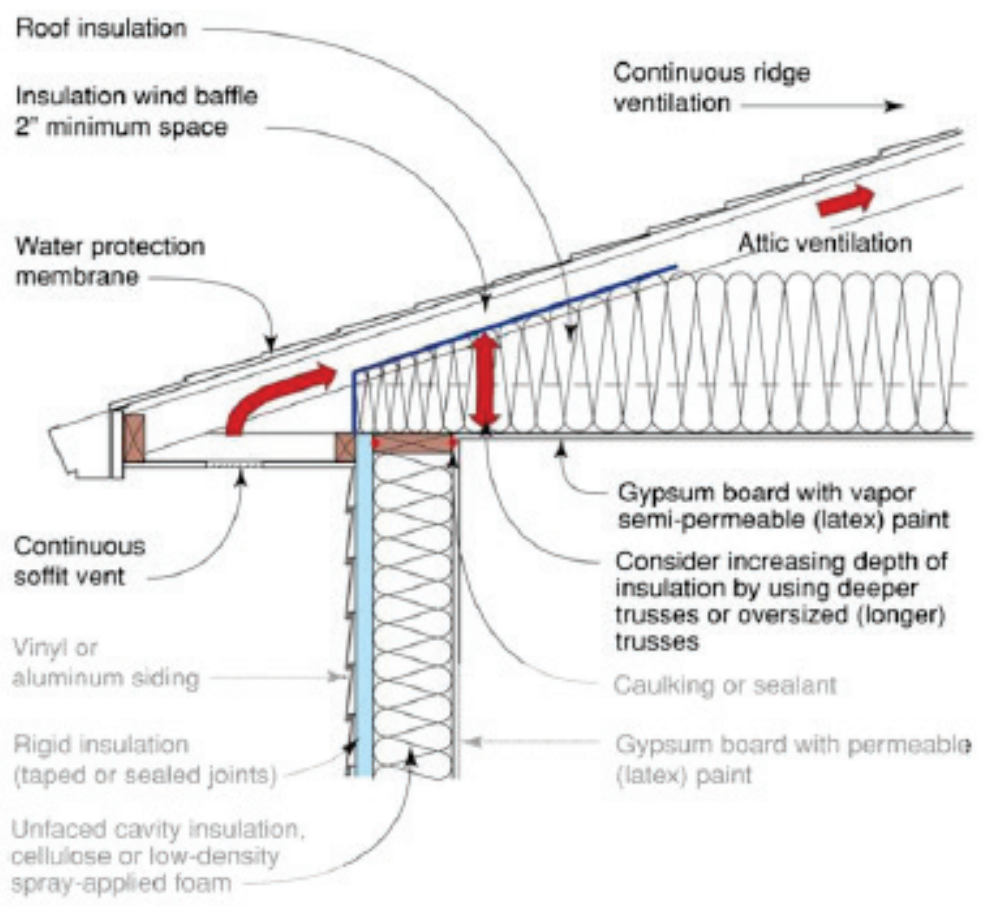

Figure 5. Vented attic

(Straube \& Grin, 2010)

Table 5. Minimum R-Value for Rigid Foam on Top of Roof Sheathing (Green Building Advisor, 2011)

\begin{tabular}{|c|c|}
\hline Climate Zone & $\begin{array}{c}\text { Rigid Foam on Top of Roof Deck } \\
\text { Minimum R-value }\end{array}$ \\
\hline $\mathbf{1 - 3}$ & 5 \\
4C & 10 \\
4A and 4B & 15 \\
$\mathbf{5}$ & 20 \\
$\mathbf{6}$ & 25 \\
$\mathbf{7}$ & 30 \\
$\mathbf{8}$ & 35 \\
\hline
\end{tabular}




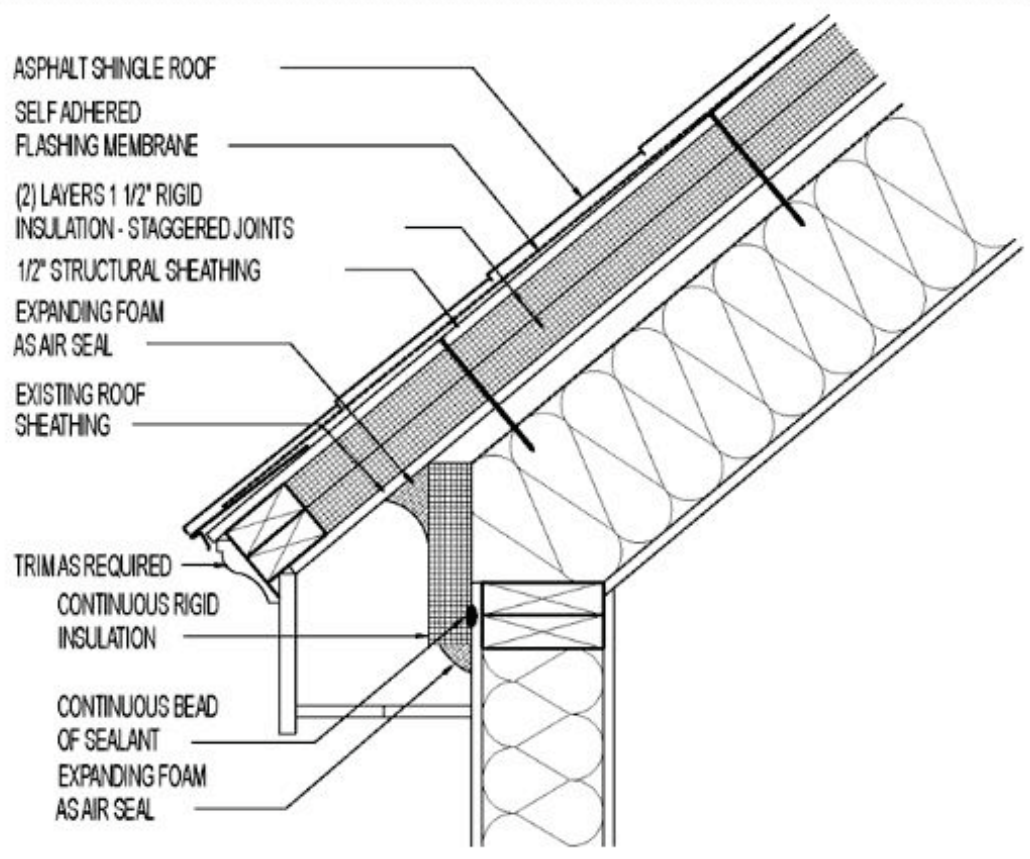

Figure 6. Unvented cathedral ceiling

(Green Building Advisor, 2008)

When venting a cathedral ceiling, install the rigid insulation between the rafters and the ceiling if more insulation is needed and it will not fit within the rafter depth and still allow for ventilation. See Figure 7.

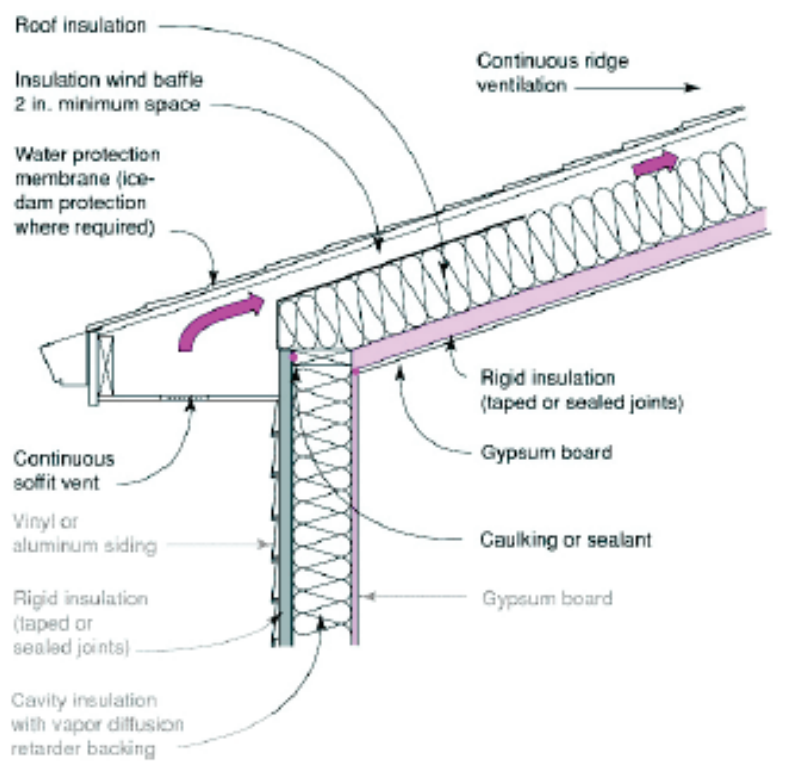

Figure 7. Vented cathedral ceiling

(Straube \& Grin, 2010) 


\subsubsection{Roofing Material}

Dark colored, non-reflective roofing can cause an attic to be $20^{\circ} \mathrm{F}$ hotter than the rest of the home. Replacing dark materials with reflective and light-colored materials can prevent increased heat transfer in the attic. Recommended roof products that reflect heat from the sun are available from the ENERGY STAR website (www.energystar.gov). This strategy can lower roof surface temperatures by up to $100^{\circ} \mathrm{F}$. This can reduce the amount of air conditioning needed in a building by reducing peak cooling demand by $10 \%-15 \%$. Cool roofs provide the most savings in climate zones 1-3 (Department of Energy, 2010). For other locations, the DOE Cool Roof Calculator can estimate savings: http://www.ornl.gov/sci/roofs+walls/facts/CoolCalcEnergy.htm. Note that this calculator is for flat roofs.

\subsubsection{Overhangs}

If the roof decking and framing are replaced, consider increasing overhangs for heat gain avoidance and increased wall durability. See Table 6 for a summary of EEMs to be considered when replacing the roof:

Table 6. EEMs To Consider When Replacing the Roof

\begin{tabular}{|c|c|}
\hline Roof Replacement & Potential Concurrent EEMs \\
\hline \multicolumn{2}{|r|}{ Air Sealing } \\
\hline Over Unvented Cathedral Ceiling & Air seal at the ceiling plane (see PNNL and ORNL 2011) \\
\hline \multicolumn{2}{|l|}{ Over Vented Cathedral Ceiling } \\
\hline Over Attic & Air seal at the ceiling plane (see Lstiburek 2012) \\
\hline \multicolumn{2}{|c|}{$\begin{array}{l}\text { Insulation: } \\
\text { Assess whether the roof/ceiling needs additional insulation, see Table } 4 .\end{array}$} \\
\hline Over Unvented Cathedral Ceiling & $\begin{array}{l}\text { Add insulation to an unvented cathedral ceiling, consider } \\
\text { adding rigid insulation above the roof deck, see Figure } 6 .\end{array}$ \\
\hline Over Vented Cathedral Ceiling & $\begin{array}{l}\text { Add insulation to a vented roof above a cathedral ceiling; } \\
\text { consider rigid insulation on the underside of the rafters. } \\
\text { (See Figure } 7 \text { and Straube and Grin 2010.) }\end{array}$ \\
\hline Over Attic & $\begin{array}{l}\text { Add insulation to the attic (see Figure } 5 \text { and Straube and } \\
\text { Grin 2010). }\end{array}$ \\
\hline \multicolumn{2}{|c|}{ 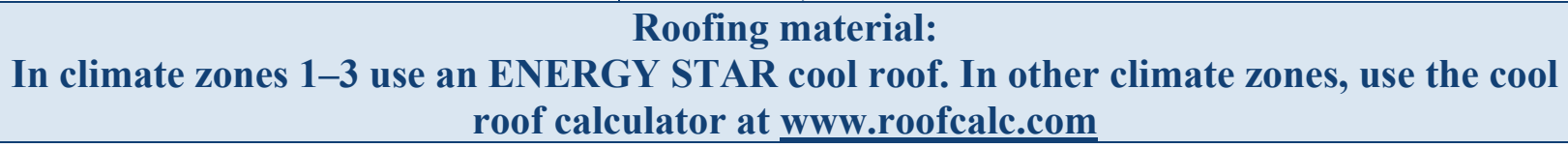 } \\
\hline $\begin{array}{r}\text { If roof framing is replace } \\
\text { av }\end{array}$ & $\begin{array}{l}\text { Overhangs: } \\
\text { ider incorporating increased overhangs for heat gain } \\
\text { and increased wall durability. }\end{array}$ \\
\hline
\end{tabular}

\subsubsection{Siding}

Infiltration is recognized as one of the biggest energy wasters in single-family homes. U.S. Environmental Protection Agency studies have found that, in a typical American house, infiltration accounts for $25 \%-40 \%$ of the heating and cooling loads (EPA, 2000). While air sealing from inside the home can improve its tightness, sealing a home from the outside could potentially be a much more effective approach. Considering that every year thousands of homes are re-sided for maintenance and aesthetic reasons, the potential to improve energy efficiency as well is immense. 
To investigate the potential for this approach, in 2011, The Center for Building Knowledge at the New Jersey Institute of Technology began an exterior air sealing study entitled "Re-side Tight Ventilate Right." Prior to homes being re-sided, contractors properly installed air barriers over the old siding or sheathing. Participating contractors were compensated at the rate of $\$ 1,000$, plus materials, for the additional time needed for their siding employees to install the air barrier. In each instance, Center for Building Knowledge staff members also requested that the contractors apply spray foam to any large exposed gaps on the exterior of the dwelling. Blower door testing before and after the siding work measured the change in leakage and determined whether to introduce mechanical ventilation. Of 10 homes included in the project where the air barrier was properly installed, the average reduction in air leakage was roughly $20 \%$. None of the homes was tightened to a level that required mechanical ventilation.

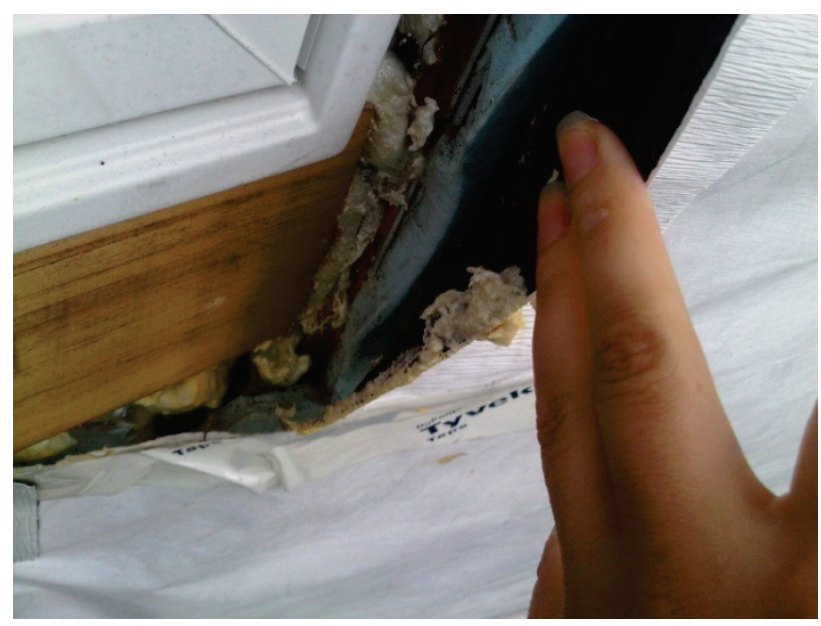

Figure 8. Window flashing 1: windows need to be properly flashed to avoid air leakage and water penetration.

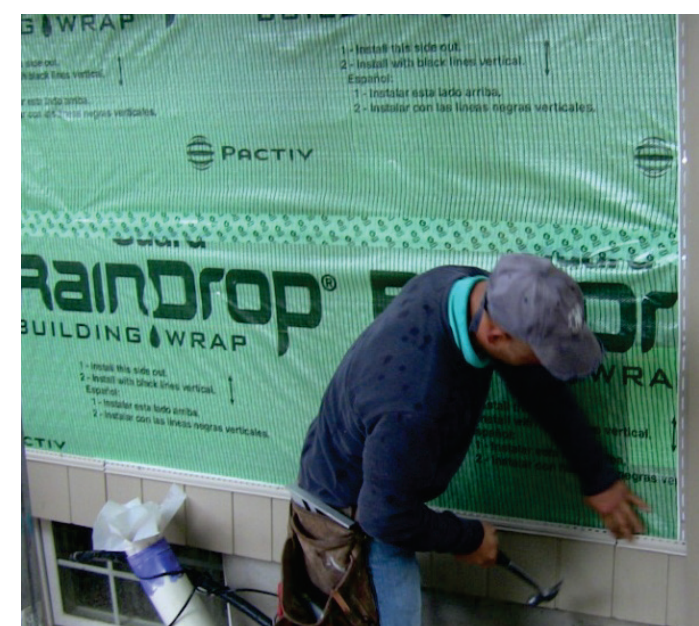

Figure 9. Air barrier 1: all seams need to be taped so the air barrier is continuous.

The major obstacle in this approach is to bring systems thinking to the remodeling world. Rather than seeing themselves as isolated specialists, the siding contractors can become the building envelope specialists, ensuring that durability and energy are addressed. The other obstacle is the common belief that making buildings tight is not a good idea because buildings need to breathe.

Siding contractors need to ensure that the top and bottom of each level of the certified air barrier is caulked to prevent air penetration. Each seam needs to be taped and all the windows need to be flashed with a self-adhered flashing. This has not been common practice. The literature published by the air barrier manufacturers states that the windows need to be flashed and provides further instructions on how to flash a window properly. This practice also coincides with ASTM E2112 Standard Practice for Installing of Exterior Windows.

While installing the air barrier on the exterior prior to siding, homeowners can add some R-value to their walls by having the siding contractor nail rigid foam to the exterior sheathing. This strategy requires that a minimum amount of R-value is added, as deemed by the 2009 IRC (see Figure 10), in order to avoid moisture issues. Another option is to choose a siding product with insulation laminated to the back. The R-value offered by most of these products is in the 2.5 range. This strategy does not increase labor costs versus conventional siding. In 2011, the Vinyl 
Siding Institute began a study on the effect of using siding with insulation versus siding without. The insulated vinyl siding added an additional R-2.6 to the homes in the study. The study's energy modeling showed savings that ranged from 5\%-12\%, with an average of $8 \%$ across the four homes in the study (Vinyl Siding Institute, 2011). The caveat with this approach is that the vinyl siding and insulation are relatively impermeable. As such, if the R-value does not meet the requirements from the 2009 IRC for exterior foam sheathing (see Figure 10), it should be installed over rigid insulated sheathing to meet the code requirement.

\begin{tabular}{|l|l|}
\hline Climate Zone & Minimum R-Value of Foam Sheathing \\
\hline Marine Zone 4 & $\mathrm{R}-2.5$ for $2 \times 4$ walls; R-3.75 for $2 \times 6$ walls \\
\hline Zone 5 & R-5 for $2 \times 4$ walls; R-7.5 for $2 \times 6$ walls \\
\hline Zone 6 & R-7.5 for $2 \times 4$ walls; R-11.25 for $2 \times 6$ walls \\
\hline Zones 7 and 8 & R-10 for $2 \times 4$ walls; R-15 for $2 \times 6$ walls \\
\hline
\end{tabular}

Figure10. IRC foam sheathing requirements

(Holladay, 2010)

Table 7 is a summary of EEMs to be considered when installing siding.

Table 7. EEMs To Consider When Installing Siding

\begin{tabular}{c|c}
\hline Siding & \begin{tabular}{c} 
Potential Concurrent EEMs \\
\hline
\end{tabular} \\
$\begin{array}{r}\text { If stripping the siding to reveal the sheathing, provide a weather } \\
\text { resistant barrier over the sheathing. Install the weather resistant } \\
\text { barrier to serve as an intact air barrier. } \\
\text { If additional insulation is desired consider adding rigid } \\
\text { insulation over the weather resistant barrier, see Figure } 10 .\end{array}$ \\
\hline
\end{tabular}

\subsection{System Projects}

Repair and/or replacement of mechanical systems and modifications to electrical systems provide opportunities for energy efficiency improvements within the systems themselves; i.e., higher efficiency equipment or lighting, and beyond, such as at the distribution system or the controls. The Building America program has existing resources for mechanical system guidance in particular that are included in this section.

\subsubsection{HVAC Systems}

To determine whether a heating or cooling system needs repair or replacement, Building America has an assessment tool for heating systems, as shown in Figure 11 and for cooling in Figure 12. 


\section{Should I replace my existing heating system?}

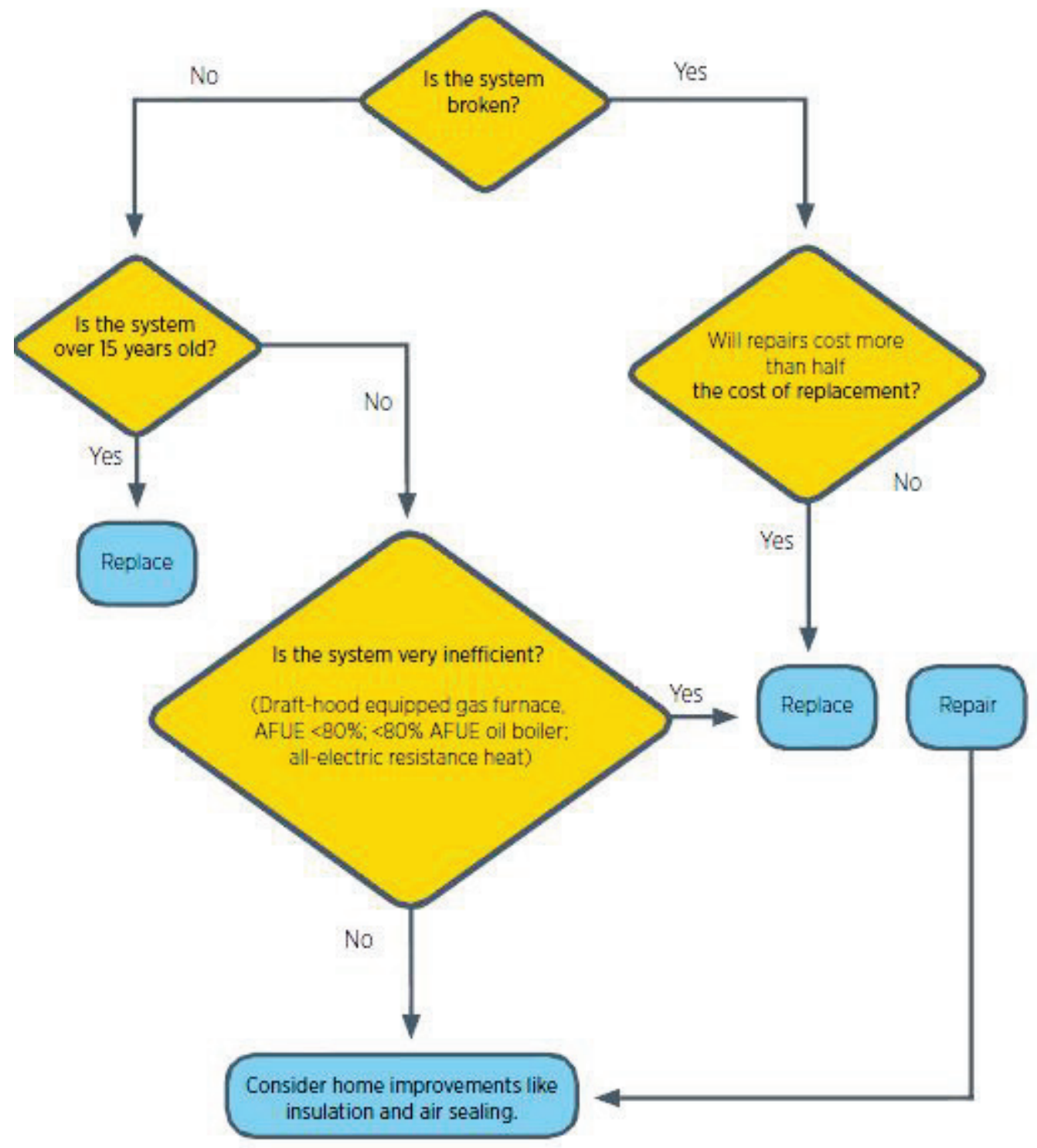

Figure 11. Basic decisions for replacing your heating system

(PNNL \& ORNL, 2011) 


\section{Should I install a new central air conditioning system?}

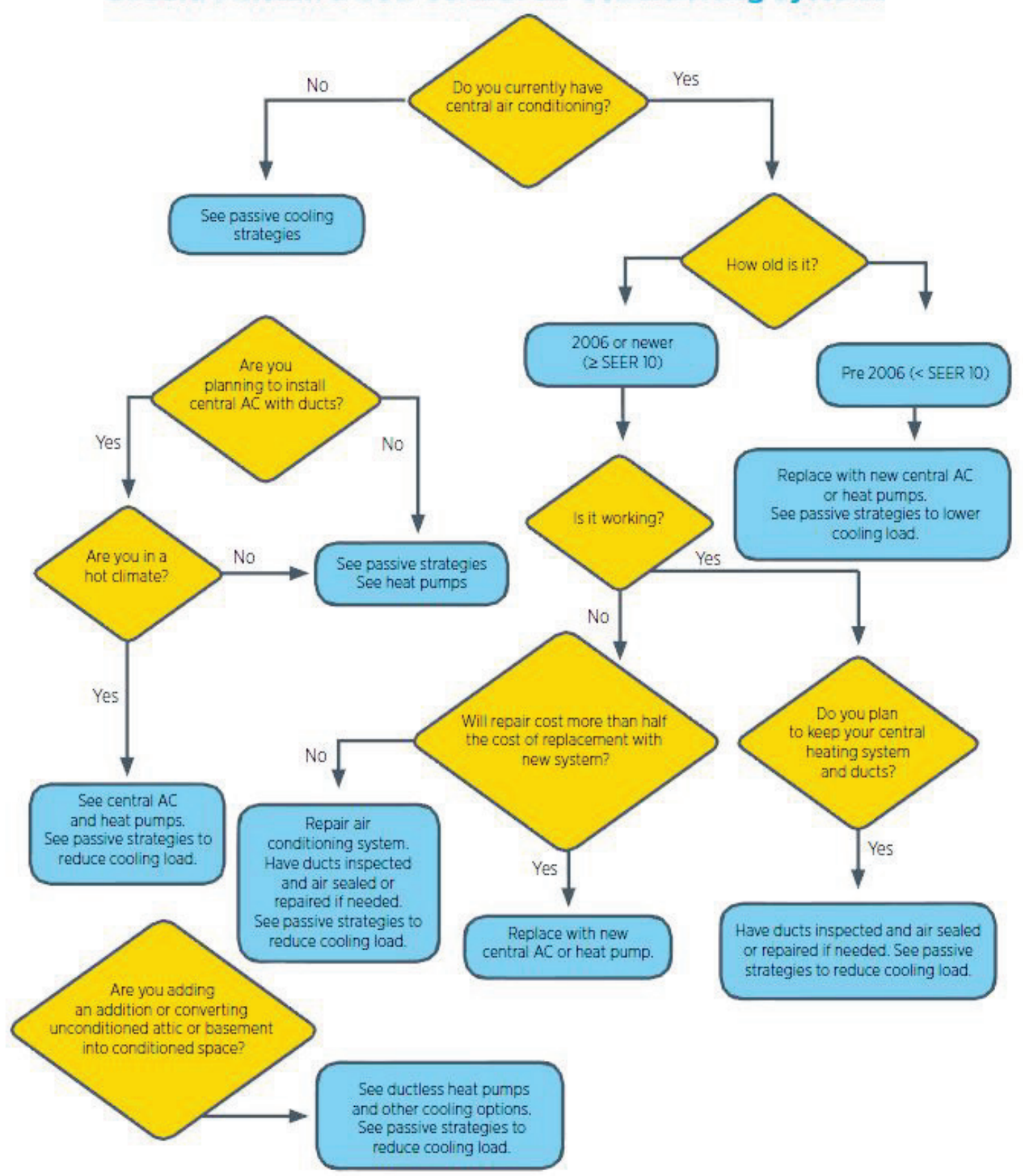

Figure 12. Basic decisions for replacing your cooling system

(PNNL \& ORNL, 2011) 
Mechanical system replacement or repair, like other remodeling projects, warrants a thorough understanding of existing conditions. Specifying the best retrofit equipment requires that a systems approach be applied to the project (LBNL, 2004). In assessing the existing conditions, the following facts are needed: inputs for heat load calculations: knowing how many people live in the dwelling; if there are pets; and if there are high energy bills. These questions help define the building loads and reveal existing mechanical system problems. Armed with this key information and the proper calculations, HVAC systems can be properly sized, potential problems can be avoided, and the total cost of the system can be kept in check (McWilliams \& Walker, 2005).

Typically, this thorough assessment of existing conditions is not part of the preparation for specifying new space conditioning equipment in an existing home. Fortunately, there is guidance based on climate and house construction (see LBNL, 2004). As seen in Figure 13, the guide provides packages of measures to be implemented, such as duct sealing, duct insulation, refrigerant charge, and installing downsized ducts and equipment. The recommended packages are grouped by the level of effort, from low to high (1-3), and broken out for the HVAC system only or the HVAC system and envelope work.

\begin{tabular}{|l|l|l|}
\hline \multicolumn{2}{|c|}{ Table 1. Recommended Retrofits for Hot-Dry, Mixed-Dry, and Marine Climates } \\
\hline $\begin{array}{l}\text { Intervention } \\
\text { Level }\end{array}$ & HVAC System Only & HVAC System Plus Envelope \\
\hline 1 & $\begin{array}{l}\text { Ducts sealed (leakage decreased } \\
\text { to }<10 \% \text { of air handler flow). Ducts } \\
\text { outside conditioned space insulated } \\
\text { to R-8. Correct refrigerant charge. }\end{array}$ & $\begin{array}{l}\text { Ducts sealed (leakage decreased to }<10 \% \text { of air handler flow). Ducts outside conditioned space } \\
\text { insulated to R-8. Correct refrigerant charge. Ducts sealed and buried in added ceiling insulation. } \\
\text { New downsized ducts and HVAC equipment. The ducts are installed to minimize the flow } \\
\text { resistance, i.e. correct length, good routing, and preferably sheet metal construction. }\end{array}$ \\
\hline 2 & $\begin{array}{l}\text { Ducts sealed (leakage decreased } \\
\text { to }<10 \% \text { of air handler flow). } \\
\text { Ducts outside conditioned space } \\
\text { insulated to R-8. Correct refrigerant } \\
\text { charge. Added economizer. }\end{array}$ & $\begin{array}{l}\text { Ducts sealed (leakage decreased to < } 10 \% \text { of air handler flow). Ducts outside conditioned space } \\
\text { insulated to R-8. Correct refrigerant charge. Ducts sealed and buried in added ceiling insulation. } \\
\text { New downsized ducts and HVAC equipment. The ducts are installed to minimize the flow } \\
\text { resistance, i.e. correct length, good routing, and preferably sheet metal construction. } \\
\text { Added economizer. }\end{array}$ \\
\hline 3 & $\begin{array}{l}\text { Ducts sealed (leakage decreased } \\
\text { to }<10 \% \text { of air handler flow). Ducts } \\
\text { outside conditioned space insulated } \\
\text { to R-8. Correct refrigerant charge. } \\
\text { Added economizer. }\end{array}$ & $\begin{array}{l}\text { Ducts sealed (leakage decreased to <10\% of air handler flow). Ducts outside conditioned space } \\
\text { insulated to R-8. Correct refrigerant charge. Ducts sealed and buried in added ceiling insulation. } \\
\text { New downsized ducts and HVAC equipment. The ducts are installed to minimize the flow } \\
\text { resistance, i.e. correct length, good routing, and preferably sheet metal construction. Higher solar } \\
\text { reflectance roof. More window shading (or windows with lower SHGC). }\end{array}$ \\
\hline
\end{tabular}

Figure 13. System guidance from DOE Best Practices Guide for Residential HVAC Retrofits

(LBNL and BSC, 2005)

The Best Practices Guide also recommends that duct runs be reconsidered if they will be exposed by other retrofit efforts. Consolidated runs within the condition space are best.

Table 8 shows a summary of EEMs to be considered when replacing an HVAC system.

Table 8. EEMs To Consider When Replacing HVAC Systems

\begin{tabular}{c|r}
\hline HVAC & $\begin{array}{r}\text { Determine if a system should be repaired or replaced, for heating systems } \\
\text { (see Figure 11); for cooling systems see Figure 12. } \\
\text { Systems }\end{array}$ \\
& $\begin{array}{r}\text { If repairing the existing duct system, see CARB (2011). } \\
\text { If replacing the system, see PNNL and ORNL (2011). }\end{array}$ \\
\hline
\end{tabular}




\subsubsection{Electrical Systems}

As noted in earlier, appliances and electronics accounted for $31 \%$ of energy used in homes in 2005.

\subsubsection{Lighting}

Lighting accounts for nearly 9\% of residential energy consumption (Green Building Advisor, 2011). When changing to more efficient lighting, most gains will come from reduced electrical use. However, if there are existing recessed lights in the building's thermal envelope, changing to surface mounted lights can reduce heat loss, air leakage, and the potential for condensation.

\subsection{Compact Fluorescent Lamps and Light-Emitting Diodes}

Traditional incandescent bulbs produce mostly heat; only a small portion of the energy they consume produces light. Compact fluorescent lamps (CFLs) use less power to produce the same amount of light as an incandescent. Lower wattage CFLs can be used to replace incandescent bulbs. In addition, CFLs last up to 10,000 hours (average incandescents last 1,500 hours). Though more expensive, switching to CFLs "is the single most cost-effective way to save residential energy, reducing power consumption for lighting by 75\%" (Green Building Advisor, 2011).

Light-emitting diodes (LEDs) are another alternative to incandescent bulbs. Most LED fixtures produce 11-25 lumens/W. This is less efficient than the average CFL at 48-80 lumens/W. LEDs last longer, however, at an average of 30,0000-50,000 hours. Unlike CFLs, LEDs contain no mercury (Green Building Advisor, 2011).

For both CFLs and LEDs, choose ENERGY STAR lamps and fixtures.

\subsection{Vacancy Sensors}

The use of vacancy sensors for residential lighting appears to have promising potential for energy savings. Vacancy sensors turn off lights when spaces are unoccupied for anywhere from 5 to 30 minutes, depending on the programmed setting. A key distinction between vacancy sensors and occupancy sensors is that with vacancy sensors the lights are manually turned on and will not come on automatically when the room is entered. This allows for potentially deeper savings because the occupant can chose to leave the lights off if there is sufficient daylight or they are only entering the room briefly. An impact analysis study done in 2003 for California's Title 24 found that vacancy sensors could save as much as $20 \%$ in lighting energy. It is projected in another study (through the Public Interest Energy Research Buildings Program) that bathroom vacancy sensors could reduce lighting energy use by $40 \%$. The potential for vacancy sensors to reduce lighting energy use in residences is currently being studied by the Center for Building Knowledge at the New Jersey Institute of Technology. Studies in other building types have shown savings in the range of $20 \%$.

\subsubsection{Smart Meters}

A smart meter is an electric meter that provides detailed, real-time statistics on electricity usage in the home and relays that information remotely to the utility company. Smart meters are similar in size to traditional meters but have a digital display. Smart meters are installed by the utility company. The installation typically takes 15-20 minutes (SDG\&E, 2010). Smart meters can be installed anytime; therefore, they do not align directly with remodeling activities. 
Smart meters are a key feature of the smart grid designed to maximize the efficiency of each part of the energy delivery system: generation, transmission, distribution, and consumption. Using a smart meter, homeowners can learn about and modify their power usage immediately. Homeowners can also track the energy fed back into the distribution network from cogeneration sources such as wind turbines and solar panels.

There has been some controversy around smart meters from the consumer perspective. Consumers criticized smart meters, believing them to be ineffective and unhealthy. An editorial by Alan Meier blames consumer skepticism on "the miserable job that the utilities, regulatory authorities, and governments have done in deploying smart meters" including "unfortunate technology choices, terrible public relations, timid public policy and unrealistic expectations" (Meier, 2011). Meier urges utility companies and regulators to maximize the benefits of smart meters to the public and provide information to consumers. Homeowners can then be empowered to evaluate and decrease their power usage and lower their utility bill by tracking their consumption with a smart meter.

\subsubsection{Smart Power Strips}

A report from the National Renewable Energy Laboratory (NREL) describes miscellaneous electric loads (MELs) to be all plug loads (televisions, stereos, microwaves) along with all hardwired loads (doorbells, security systems, garage door openers) that do not fit into other major end-use categories (space conditioning, domestic hot water, ventilation, major appliances, and lighting). Optimizing energy efficiency in MELs is especially challenging because their purchase and operation are largely under the control of the occupants. However, "if no steps are taken to address MELs, they can constitute 40\%-50\% of the remaining source energy use in homes that achieve $60 \%-70 \%$ whole house energy savings, and this percentage is likely to increase in the future as home electronics become even more sophisticated and their use becomes more widespread" (Hendron \& Eastment, 2006). One way to reduce MELs is through the use of smart power strips. Some use an occupancy sensor and power down devices after a space is unoccupied for a set period of time, and power them back up when a user returns. Others shut down power when devices go into standby mode.

Table 9 shows a summary of EEMs to be considered when installing electrical systems.

Table 9. EEMs To Consider When Installing Electrical Systems

\begin{tabular}{c|c}
\hline Electrical Systems & Potential Concurrent EEMs \\
\hline Lighting & $\begin{array}{c}\text { Use surface mounted rather than recessed } \\
\text { lighting at the building's thermal envelope }\end{array}$ \\
Meters & Specify ENERGY STAR lighting \\
MELs & Use vacancy sensor switches \\
\hline
\end{tabular}

\subsection{Combination Projects (Envelope and Systems)}

Combination projects involve both the envelope and some aspect of either the mechanical and/or electrical and/or plumbing system. The data from Table 1 show that these project types also often have larger budgets. (The average expenditure for a major kitchen remodel is $\$ 20,556$, the highest expenditure of all the items on the list.) The increased budget and wider scope of work of 
some of these project types provide the opportunity for broader EEMs, such as more extensive air sealing and insulating, than might be practical in smaller scale projects.

\subsubsection{Room Additions Other Than Kitchens, Bedrooms, and Bathrooms}

This category considers projects such as creating a finished recreation room from an unfinished space (such as finishing a basement), creating another inside room from an unfinished space, adding a room to the home, and creating a room through structural changes.

When creating a finished basement, windows may need to be enlarged for egress purposes. As such, high performance windows should be specified and installed properly (see Section 3.1.1). Adding glazing to the basement will affect the heating and cooling loads of the home and have to be considered in relation to the mechanical system.

If ceiling heights allow, adding rigid insulation over top of the basement slab can improve comfort in the space and help avoid moisture problems. This requires careful detailing. See Ueno and Lstibureck (2012).

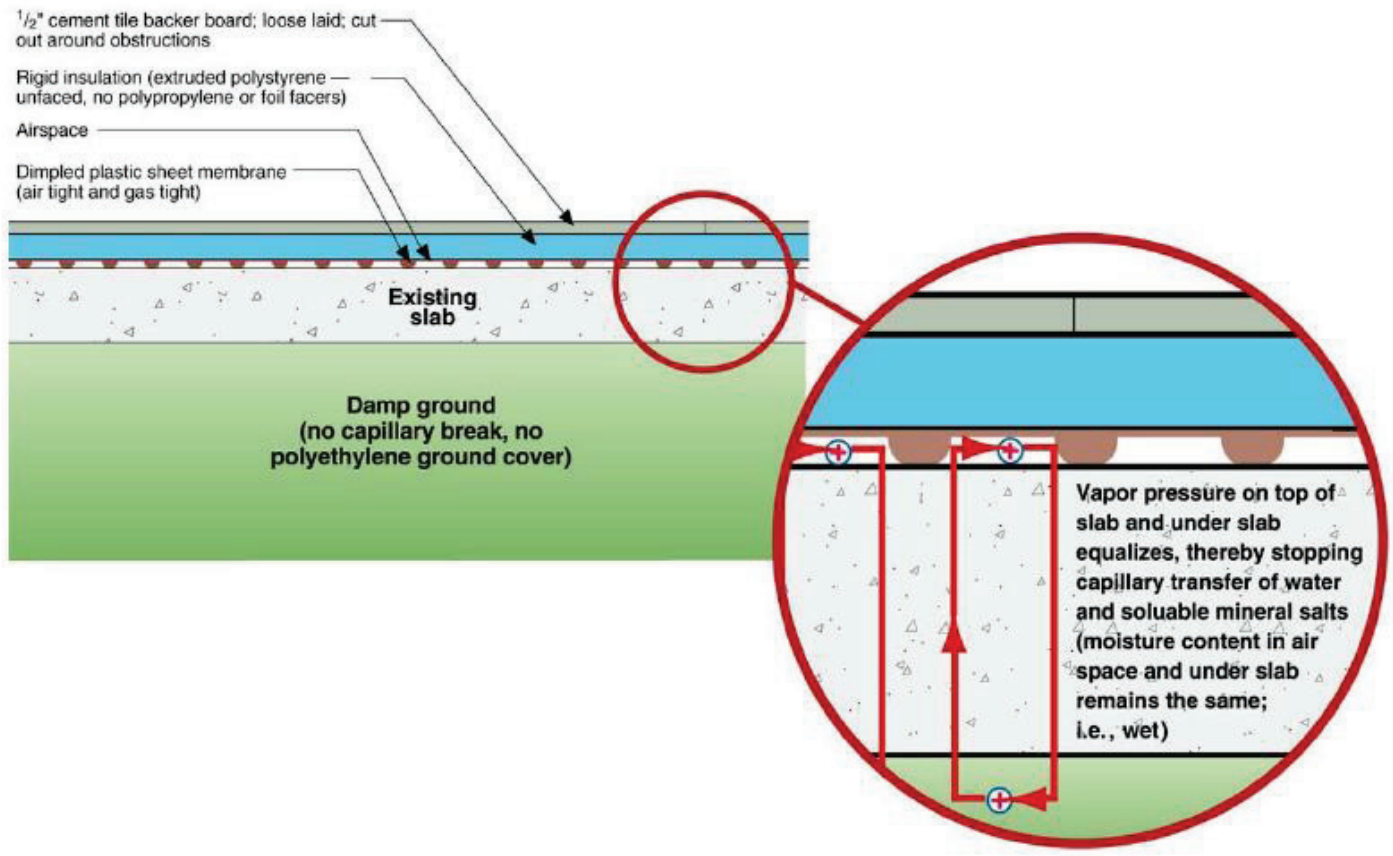

Figure 36. Use of air gap membrane and insulation as a "wet slab" retrofit

Figure 14. Use of air gap membrane and insulation as a "wet slab" retrofit

(Ueno \& Lstibureck, 2012)

It is also critical to be sure that surface water is managed properly so that a finished basement is not taking on liquid water (Lstiburek and Brennan, 2004). Whether soil gases are present and need to be venting should also be assessed. See Lstiburek and Brennan (2001).

The joint between a foundation wall and sill plate is a known site for air leakage and should be properly sealed before finishing the basement. If the exterior of the basement walls can be 
insulated, doing so can provide good thermal performance and help manage moisture. This is typically difficult or prohibitively expensive for existing basements. When insulating on the interior of the walls, moisture-tolerant materials are recommended as are non-paper faced gypsum. Optimized assemblies for moisture management based on climate can be chosen from the Building America Best Practices Series (see example in Figure 15). While these documents are geared toward new construction, the vapor profile of the basement wall in different climates is addressed and provides helpful guidance for existing homes.

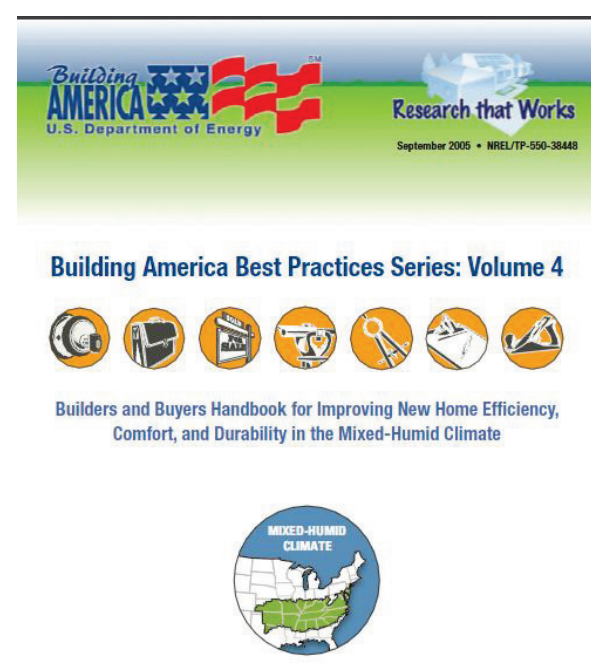

(2) Buthing Tecthologies Program

Figure 15. Example Building America Best Practice Series

(PNNL \& ORNL 2009)

An assembly designed for existing basements is shown in Figure 16. Insulation levels should meet or exceed 2009 International Energy Conservation Code (IECC) levels, shown in Figure 17 and achieve Grade 1 Installations per Residential Energy Services Network standards.

When adding a room onto the home, the size should be considered carefully. Additions should be large enough to meet the homeowners' needs and nothing more. The less square footage added, the less the operating expenses will be.

The envelope should be designed with attention paid to air sealing details and optimized insulation packages. Thorough air sealing works in all climates and specific insulation levels are climate dependent. Since the walls are being built new, insulation levels should meet the Building America Builder's Challenge/ENERGY STAR Version 3 prescriptive packages. These require that envelope components meet or exceed 2009 IECC levels and achieve Grade 1 Installations per Residential Energy Services Network standards (EPA, 2011). 


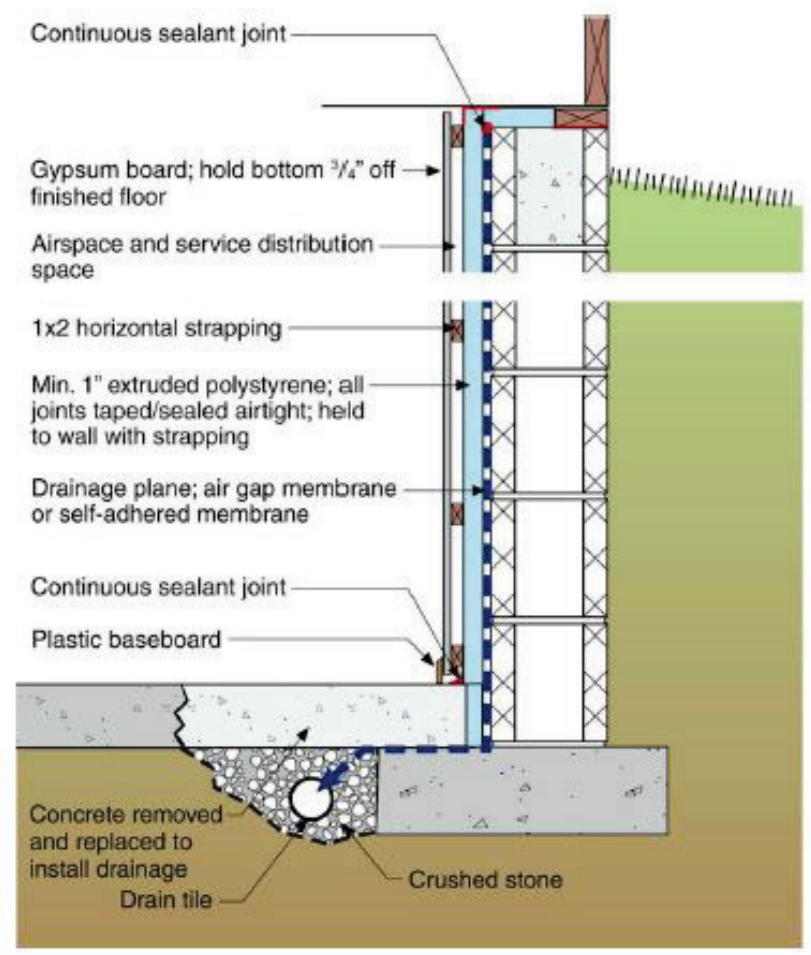

Figure 16. Interior rigid insulation and drainage

(Ueno \& Lstibureck, 2012)

TABLE 402.1.3

EQUIVALENT U-FACTORS ${ }^{\mathrm{a}}$

\begin{tabular}{|c|c|c|c|c|c|c|c|c|}
\hline $\begin{array}{c}\text { CLIMATE } \\
\text { ZONE }\end{array}$ & $\begin{array}{c}\text { FENESTRATION } \\
\text { U-FACTOR }\end{array}$ & $\begin{array}{c}\text { SKYLIGHT } \\
\text { U-FACTOR }\end{array}$ & $\begin{array}{c}\text { CEILING } \\
\text { U-FACTOR }\end{array}$ & $\begin{array}{c}\text { FRAME } \\
\text { WALL } \\
\text { U-FACTOR }\end{array}$ & $\begin{array}{c}\text { MASS WALL } \\
\text { U-FACTOR }\end{array}$ & $\begin{array}{c}\text { FLOOR } \\
\text { U-FACTOR }\end{array}$ & $\begin{array}{c}\text { BASEMENT } \\
\text { WALL } \\
\text { U-FACTOR }\end{array}$ & $\begin{array}{c}\text { SPACE } \\
\text { WALL } \\
\text { U-FACTOR }\end{array}$ \\
\hline 1 & 1.20 & 0.75 & 0.035 & 0.082 & 0.197 & 0.064 & 0.360 & 0.477 \\
\hline 2 & 0.65 & 0.75 & 0.035 & 0.082 & 0.165 & 0.064 & 0.360 & 0.477 \\
\hline 3 & 0.50 & 0.65 & 0.035 & 0.082 & 0.141 & 0.047 \\
\hline 4 except Marine & 0.35 & 0.60 & 0.030 & 0.082 & 0.141 & 0.047 & $0.091^{\mathrm{c}}$ & 0.136 \\
\hline 5 and Marine 4 & 0.35 & 0.60 & 0.030 & 0.057 & 0.082 & 0.033 & 0.059 \\
\hline 6 & 0.35 & 0.60 & 0.026 & 0.057 & 0.060 & 0.033 & 0.050 \\
\hline 7 and 8 & 0.35 & 0.60 & 0.026 & 0.057 & 0.057 & 0.028 & 0.050 \\
\hline
\end{tabular}

a. Nonfenestration $U$-factors shall be obtained from measurement, calculation or an approved source.

b. When more than half the insulation is on the interior, the mass wall $U$-factors shall be a maximum of 0.17 in Zone $1,0.14$ in Zone $2,0.12$ in Zone $3,0.10$ in Zone 4 except Marine, and the same as the frame wall $U$-factor in Marine Zone 4 and Zones 5 through 8.

c. Basement wall $U$-factor of 0.360 in warm-humid locations as defined by Figure 301.1 and Table 301.2.

d. Foundation $U$-factor requirements shown in Table 402.1.3 include wall construction and interior air films but exclude soil conductivity and exterior air films $U$-factors for determining code compliance in accordance with Section 402.1.4 (total UA alternative) of Section 405 (Simulated Performance Alternative) shall be modified to include soil conductivity and exterior air films.

Figure 17. 2009 IECC insulation requirements

(Table 402.1.3. Excerpted from the 2009 International Energy Conservation Code, Copyright 2009; Washington, D.C. International Code Council. Reproduced with permission. All rights reserved. www.ICCSAFE.org) 
Air sealing of the walls can be done using the airtight drywall approach. This strategy takes advantage of the fact that air will not pass through gypsum board. If it is properly adhered, using caulk or gaskets, to the wall framing, it can serve as an intact air barrier. The gypsum is to be sealed to the top plate, bottom plate, and any wall opening framing. Another approach is the simple caulk and seal method. For this method, joints between sheets of drywall and other gaps and openings are sealed after the drywall is installed. While this method does not allow for access to potentially hidden cavities, as the airtight drywall approach method does, testing has shown that both methods result in comparable energy savings (DOE, 2011).

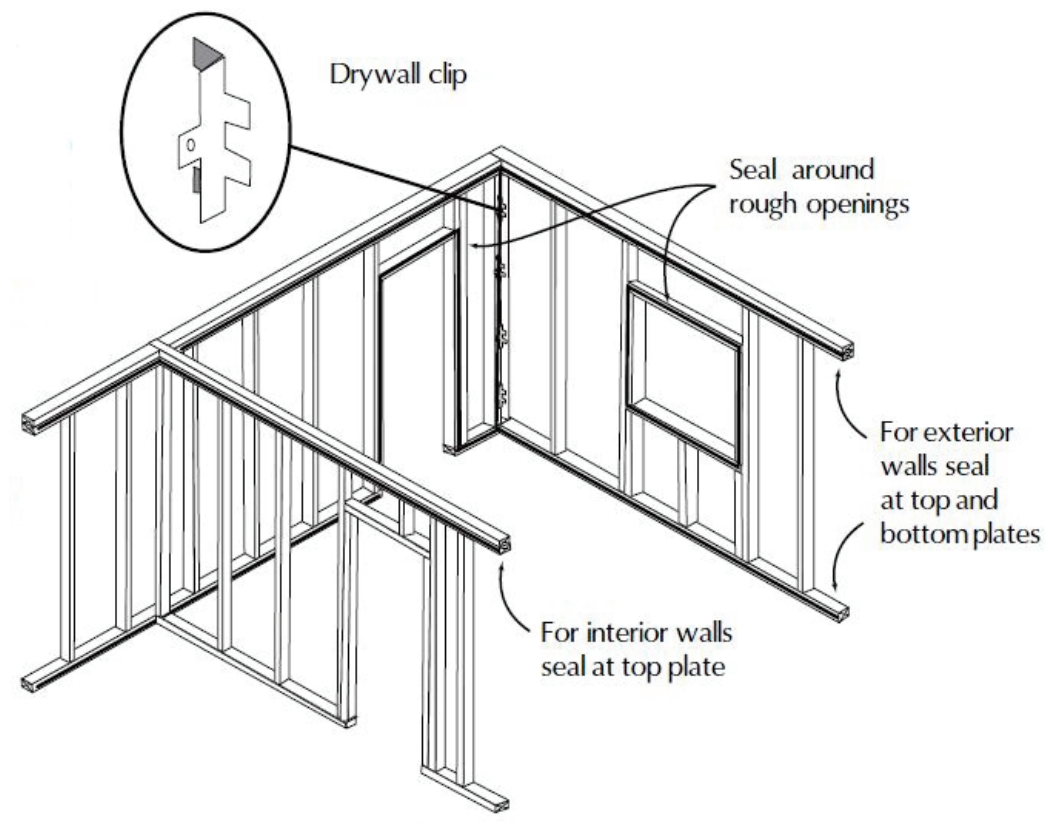

Figure 18. Airtight drywall approach

(Southface Energy Institute, 2002)

The replacement or addition of new flooring may provide an opportunity to improve the air tightness of a home. If finish flooring is being replaced, the existing subflooring can be sealed while it is exposed. This only makes sense if the floor is over an unconditioned space, such as a basement or garage, or if the floor is cantilevered. In these conditions, air sealing joints in the subfloor and at penetrations in the floor can reduce infiltration in that space. Much like the airtight drywall approach, this strategy takes advantage of the fact that sheet goods (such as oriented strand board or plywood) can block airflow as long as the joints between sheets and penetrations through sheets are sealed. Where flooring is replaced in rooms with exterior wall area, subflooring can also be sealed to the bottom of the exterior wall drywall. How much these tasks will reduce overall infiltration is highly dependent on the area of flooring being replaced and the linear feet of exterior wall involved. In instances where the floor and or wall area is relatively small, air sealing can still be beneficial in that specific location for reducing drafts and minimizing indoor air quality issues and durability problems that can arise from infiltration.

Table 10 shows a summary of EEMs to be considered when adding a room. 
Table 10. EEMs To Consider When Adding a Room

\begin{tabular}{c|c}
\hline $\begin{array}{c}\text { Room Additions Other Than } \\
\text { Kitchens, Bedrooms, and } \\
\text { Bathrooms }\end{array}$ & Potential Concurrent EEMs \\
\hline $\begin{array}{c}\text { Creating Finished Basement } \\
\text { Air Sealing }\end{array}$ & $\begin{array}{c}\text { If incorporating windows, see "Windows" above } \\
\text { Air seal between the foundation wall and framing }\end{array}$ \\
Insulate & $\begin{array}{c}\text { Insulate the basement walls } \\
\text { (see Ueno and Lstiburek 2012) }\end{array}$ \\
Adding a Room & $\begin{array}{c}\text { If ceiling heights allow, add insulation over the slab } \\
\text { Air Sealing size to meet programmatic needs and no more }\end{array}$ \\
Insulate & Air seal using the air tight drywall approach \\
(see Figure 18)
\end{tabular}

\subsubsection{Bath Remodels}

As defined by the American Housing Survey, major bath remodels involve professional home improvements of more than \$5,000 (Joint Center for Housing Studies of Harvard University, 2011). The five key areas for energy efficiency in a bathroom remodeling project include hot water, lighting, insulation, air sealing, and ventilation. Enhancing energy efficiency in the bathroom can often lead to improved comfort and durability and reduced risk of moisture problems (NAHB Research Center et al. 2006). The most common reasons a homeowner remodels a bathroom include upgrading the fixtures in the room, fixing leaks and water damage, and increasing or reconfiguring the room's floor plan (ASID and USGBC, 2008).

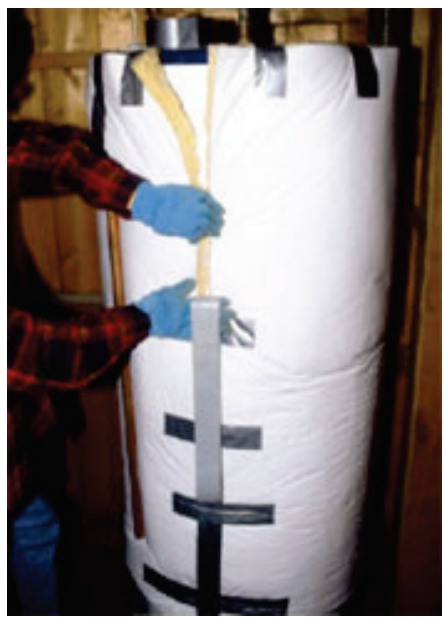

Figure 19. Water heater insulating blanket

(Source: Portal.hud.gov) 


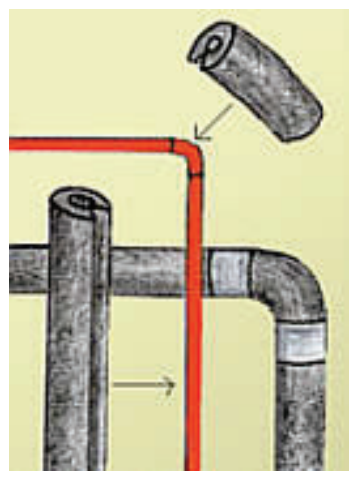

Figure 20. Hot water pipe insulation

(Source: Portal.hud.gov)

\subsubsection{Water Heating}

Bathroom hot water use accounts for $60 \%$ of total household water use. Strategies to save water heating energy include adding insulation, using efficient equipment and distribution systems, installing low-flow fixtures, repairing leaks, and drain water heat recovery. These strategies can also improve resident comfort by resolving issues such as running out of hot water and uneven hot water delivery temperature (NAHB Research Center et al. 2006). A water heater insulating blanket and/or heat traps on the inlet and outlet of an old water heater, especially if it is located in an unconditioned space, can improve hot water functioning. Hot water pipe insulation can help as well. Cross-linked polyethylene (PEX), flexible plastic hot water piping, can reduce hot water waste by reducing pipe size. PEX is also easier to run through existing walls than rigid piping. If the project calls for a new water heater, high efficiency water heating equipment should be specified; see the ENERGY STAR website (www.energystar.gov). Heat pump water heaters, condensing gas water heaters, high-efficiency gas water-storage water heaters, tankless water heaters, and solar water heating are all included on the site. See Shapiro et al. (2012) for guidance on heat pump water heater technology.

Regardless of the type of water heater used, setting the water heater's thermostat no higher than necessary (usually about $120^{\circ} \mathrm{F}$ ) can improve safety and conserve energy. The manufacturer setting may be as high as $140^{\circ} \mathrm{F}$. According to the DOE Office of Energy Efficiency and Renewable Energy, each $10^{\circ} \mathrm{F}$ reduction in water temperature saves $3 \%-5 \%$ in energy costs for water heating and also slows corrosion in the water heater and pipes, helping the water heater continue to operate efficiently (NAHB Research Center et al. 2006).

Drain water heat recovery can also be advantageous in bathroom remodels. Rather than losing the heat contained in hot water going down the drain, drain water heat recovery systems capture the heat and use it to pre-warm the cold water going to the water heater. 


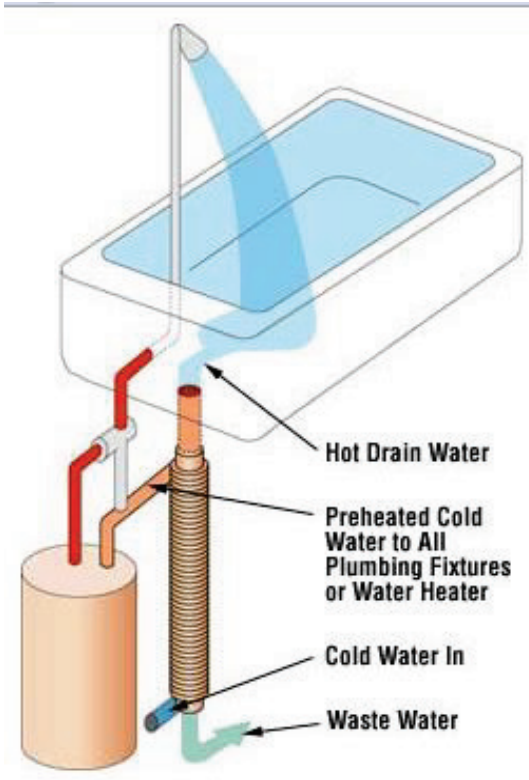

Figure 21. Drain water heat recovery

(NAHB Research Center, 2001)

\subsubsection{Water Conservation}

According to a 2001 study conducted in Seattle, leaking pipes and dripping faucets account for an average of $3.1 \mathrm{gal} / \mathrm{day} /$ household. Of that, $27 \%$, or about $1 \mathrm{gal}$, was hot water (De Oreo \& Mayer, 2001). In addition, according to the American Water Works Association, one in five toilets leak. Energy and water savings can be achieved during a remodel by adding an aerator or installing low-flow fixtures. Low-flow fixtures are inexpensive, often less than $\$ 5$, and are an effective solution in any bathroom having faucets pre-dating 1994. A study of showerhead and faucet replacement with low-flow fixtures identified a reduction in hot water use of about $12 \%$, or $7.5 \mathrm{gal} / \mathrm{day}$, and a subsequent savings of $\$ 24 / \mathrm{year}$, which is $12 \%$ of the average annual household expenditure for hot water (Energy Information Administration, 1997). In addition, switching to post-1994, high-efficiency toilets can halve the average household water consumption for toilets from about $60 \mathrm{gal} / \mathrm{day}$ to 30 (NAHB Research Center et al. 2006).

\subsubsection{Bathroom Lighting}

Types of lighting in a bathroom include task lighting and ambient lighting. Accent lighting is typically not required in a bathroom. Task lighting should be placed around the vanity, with as few shadows as possible. A moisture-rated light can provide task lighting for showers. Ambient lighting should be provided by daylight if possible, supplemented by indirect fluorescent lighting for overcast days and night. Task lighting delivers light more precisely, where it is needed and can be provided more efficiently with recessed CFLs or LED fixtures. To eliminate energy loss associated with recessed lights, insulated-contact rated recessed fixtures should be installed or recessed lights should be placed in a soffit below the insulated ceiling. Tubular skylights are a good option for bringing in daylight while minimizing energy loss (NAHB Research Center et al. 2006). To avoid solar gain, skylights may have integral blinds mounted between the panes of glass. Alternatively, electrochromic glazing relies on a small amount of electric current, activated by a push of a button, to tint the glass. 


\subsubsection{Insulation and Air Sealing}

The exterior walls behind tubs and showers are often poorly insulated and air sealed. Opening walls as part of a bathroom renovation provides an opportunity to improve thermal performance. Properly insulating bathroom walls can both improve user comfort and eliminate condensation problems. Refer to Figure 17 for climate-specific insulation levels. A variety of insulation products are available such as fiberglass batts, sprayed cellulose, mineral wool, spray foam, and rigid foam. If walls are not opened, a blown-in insulation can be used, such as cellulose, fiberglass, or cotton fiber. The type of product used is less important than the R-value achieved. All wall cavities should be filled and the insulation should be uncompressed. In addition, floors above unconditioned spaces should be insulated to IRC 2009 levels if possible; see Figure 17. Vapor retarders should not be used on the interior or exterior wall faces except for in extremely cold climates. This is because the wall cavity should be allowed to dry as the air in a bathroom is very humid and it is nearly impossible to completely seal the cavity against moisture penetration (NAHB Research Center et al. 2006).

Air sealing of bathroom walls is also an important strategy to improve comfort, reduce energy bills, and prevent condensation problems. Sealing air leaks can reduce air leakage by $25 \%$ (PATH, 2009). The water vapor in the air is likely to condense when it reaches a sufficiently cold enough point within the wall cavity. Air sealing is inexpensive, practical, and relatively simple. Common leakage pathways include: around windows and exterior doors; through recessed lights; around switches and receptacles on exterior walls; around bath fans; around plumbing penetrations including water pipes, drains, and vent stacks; through dropped ceilings; at wall intersections; and at gaps at the top of interior walls (NAHB Research Center et al. 2006).

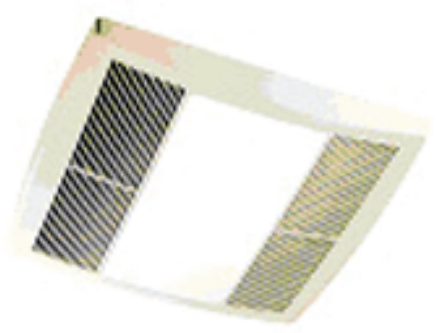

Figure 22. ENERGY STAR ventilation fan

(Source: energystar.gov)

\subsubsection{HVAC Systems}

A proper fan system can improve air quality and the longevity of the entire house by exhausting moist air that can promote mold and mildew growth. Installing quiet, efficient ventilation fans can result in more efficient equipment operation, increased fan usage, and more effective moisture removal. Twist-timers or humidistats can encourage the use of ventilation fans and ensure that they are not left on (NAHB Research Center et al. 1999). Ventilation can also be accommodated by spot energy recovery ventilators or incorporated into a central ventilation system with a port to the bathroom. 
The bathroom remodeling process may necessitate changes to the mechanical system. When bathrooms need extra heat, supplemental space heating is an alternative to changing the entire mechanical system, particularly since the bathroom is a relatively small space with intermittent use. If a new floor is being installed, radiant floor heating can be added, or, alternatively, radiant ceiling panels. Conventional heat fans or electric resistance heating are also options. For cooling, it may be advisable to install exhaust fans to facilitate circulation. Ducts could be enlarged or another supply duct could be added. Operable windows could also help cool the bathroom (NAHB Research Center et al. 1999).

Table 11 shows a summary of EEMs to consider when remodeling a bathroom.

Table 11. EEMs To Consider When Remodeling a Bathroom

\begin{tabular}{|c|c|}
\hline Bath Remodel & Potential Concurrent EEMs \\
\hline Hot Water & Add insulation to existing water heater \\
\hline Piping & Insulate hot water piping \\
\hline $\begin{array}{l}\text { Water Heater } \\
\text { Replacement }\end{array}$ & $\begin{array}{c}\text { If replacing the water heater, specify an ENERGY } \\
\text { STAR model, see www.energystar.gov } \\
\text { If considering a heat pump water heater, see } \\
\text { Shapiro et al. (2012). }\end{array}$ \\
\hline Controls & Set the water heater thermostat at $120^{\circ} \mathrm{F}$ \\
\hline Other Measures & Consider drain water heat recovery \\
\hline Water Conservation & $\begin{array}{c}\text { Use water conserving fixtures, see } \\
\text { www.epa.gov/watersense }\end{array}$ \\
\hline Lighting & $\begin{array}{l}\text { See "Lighting" under Electrical Systems above } \\
\text { Consider tubular skylights for ambient lighting }\end{array}$ \\
\hline Air Sealing & See "Air Sealing" under Adding a Room, above \\
\hline Insulation & See "Insulation” Under Adding a Room above \\
\hline HVAC Systems & Provide efficient ventilation (see BSC 2004) \\
\hline
\end{tabular}

\subsubsection{Kitchen Remodels}

As defined by the American Housing Survey, major kitchen remodels involve professional home improvements of more than $\$ 10,000$ (Joint Center for Housing Studies of Harvard University, 2011). Measures that can be incorporated into minor kitchen remodels will vary depending on the scope of work. Areas for potential energy savings in a kitchen remodel include: appliance energy, hot water, windows, lighting, insulation, air sealing, and ventilation. For all but appliances and ventilation, recommendations from Section 3.3.2 apply.

\subsubsection{Air Sealing}

Air sealing in the kitchen can be particularly critical as there are usually many wall penetrations and high levels of glazing. Air sealing details specific to the kitchen can be seen in Figure 23. 


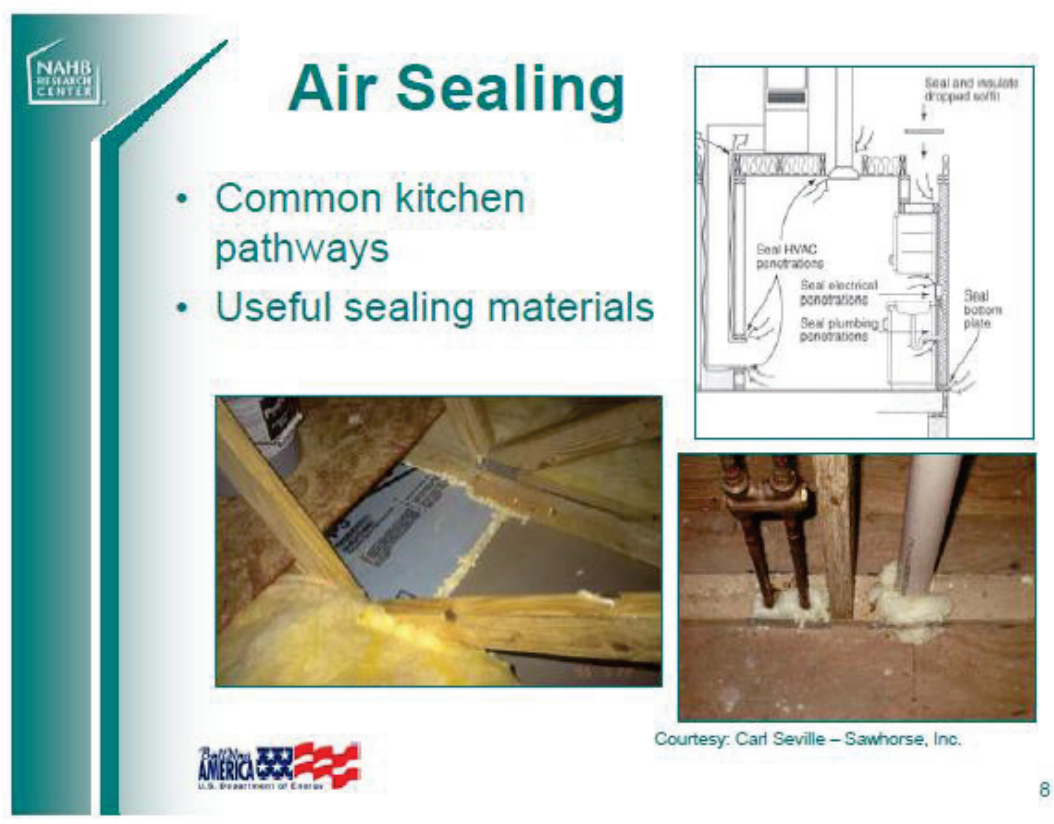

Figure 23. Kitchen air sealing

(NAHB Research Center, 2006)

Energy-efficient appliances, those that are ENERGY STAR certified and beyond, should be specified for kitchen remodels. Bottom freezer refrigerators are considered the most energy efficient type, and side-by-side the least, with top freezer models in between. Extras such as ice makers through the door reduce the energy performance and should be carefully considered. The size of refrigerator selected should meet the homeowners' needs, but not more. Larger refrigerators use more energy (ASID \& USGBC, 2008).

\subsubsection{Windows}

There is often a tendency to incorporate a lot of window glazing into kitchen renovations (ASID \& USGBC, 2008). Beyond specifying high performance glazing for the room and ensuring that it is properly installed for durability and air tightness, refraining from over glazing can provide the biggest energy savings because even really good windows are not as energy efficient as merely code compliant walls. See Section 3.1.1.

\subsubsection{HVAC Systems}

Kitchen ventilation fans should be ENERGY STAR or beyond. ENERGY STAR requires an efficacy of $2.8 \mathrm{cfm} / \mathrm{W}$ and a sound level of more than 2.0 sones (ASID \& USGBC, 2008). Spot energy recovery ventilator fans are now available and may provide an energy benefit for ventilation in the kitchen. If a heat recovery ventilator or energy recovery ventilator is providing whole house ventilation, a port to the kitchen can be incorporated. If this is done, it needs to be paired with a recirculating range hood that has a grease filter. Overpowered kitchen range hoods can cause backdrafting of other combustion appliances. The flow should be determined with ventilation calculations and equipment specified to meet the flow requirements.

Table 12 shows a summary of EEMs to be considered when remodeling a kitchen. 
Table 12. EEMs To Consider When Remodeling a Kitchen

\begin{tabular}{c|c}
\hline Kitchen Remodels & Potential Concurrent EEMs \\
\hline Lighting & See "Lighting" under Electrical Systems above \\
Air Sealing & Consider tubular skylights for ambient lighting \\
Insulation & See "Air Sealing" under Adding a Room, above \\
HVAC Systems & See "Insulation" Under Adding a Room above \\
Provide efficient ventilation, see READ THIS: Before \\
\hline
\end{tabular}




\section{Summary of Remodeling Projects and Potential Energy Efficiency Measures}

The EEMs described for potential incorporation into common remodeling projects are summarized in Table 13.

Table 13. Remodeling Projects and Potential EEMs

\begin{tabular}{|c|c|}
\hline & Envelope Projects \\
\hline \multirow{3}{*}{ Windows and Doors } & Do not replace if only pursuing energy savings \\
\hline & Specify energy star windows or better, see Figure 4 \\
\hline & $\begin{array}{l}\text { Incorporate proper air and moisture sealing strategies, } \\
\text { see Figure } 5\end{array}$ \\
\hline \multicolumn{2}{|r|}{ Roofing } \\
\hline \multicolumn{2}{|r|}{ Air Sealing } \\
\hline $\begin{array}{l}\text { Over Unvented Cathedral } \\
\text { Ceiling }\end{array}$ & \multirow{2}{*}{$\begin{array}{l}\text { Air seal at the ceiling plane } \\
\text { (see PNNL and ORNL 2011) }\end{array}$} \\
\hline $\begin{array}{c}\text { Over Vented Cathedral } \\
\text { Ceiling }\end{array}$ & \\
\hline Over Attic & Air seal at the ceiling plane (see Lstiburek 2012) \\
\hline Insulation & $\begin{array}{c}\text { Assess whether the roof/ceiling needs additional } \\
\text { insulation, see Table } 4 .\end{array}$ \\
\hline $\begin{array}{l}\text { Over Unvented Cathedral } \\
\text { Ceiling } \\
\end{array}$ & $\begin{array}{l}\text { Add insulation to an unvented cathedral ceiling, consider } \\
\text { adding rigid insulation above the roof deck, see Figure } 7 .\end{array}$ \\
\hline $\begin{array}{l}\text { Over Vented Cathedral } \\
\text { Ceiling }\end{array}$ & $\begin{array}{l}\text { Add insulation to a vented roof above a cathedral } \\
\text { ceiling; consider rigid insulation on the underside of the } \\
\text { rafters. See Figure } 8 \text { and Straube and Grin } 2010 \text {. }\end{array}$ \\
\hline Over Attic & $\begin{array}{c}\text { Add insulation to the attic } \\
\text { (see Figure } 6 \text { and Straube and Grin 2010) }\end{array}$ \\
\hline Roofing Material & $\begin{array}{c}\text { In climate zones 1-3 use an ENERGY STAR cool roof. } \\
\text { In other climate zones, use the cool roof calculator at } \\
\text { www.roofcalc.com }\end{array}$ \\
\hline \multirow{2}{*}{ Siding } & $\begin{array}{l}\text { If stripping the siding to reveal the sheathing, provide a } \\
\text { weather-resistant barrier over the sheathing. Install the } \\
\text { weather-resistant barrier to serve as an intact air barrier. }\end{array}$ \\
\hline & $\begin{array}{c}\text { If additional insulation is desired, consider adding rigid } \\
\text { insulation over the weather-resistant barrier } \\
\text { (see Figure } 11 \text { and Holladay 2010). }\end{array}$ \\
\hline \multicolumn{2}{|r|}{ System Projects } \\
\hline \multirow[t]{3}{*}{ HVAC } & $\begin{array}{l}\text { Determine if a system should be repaired or replaced; for } \\
\text { heating systems, see Figure 12, for cooling systems see } \\
\text { Figure } 13\end{array}$ \\
\hline & If repairing the existing duct system, see CARB (2011). \\
\hline & If replacing the system, see PNNL and ORNL (2011). \\
\hline
\end{tabular}




\section{Electrical Systems}

Use surface mounted rather than recessed lighting at the

\begin{tabular}{|c|c|}
\hline \multirow{3}{*}{ Lighting } & building's thermal envelope \\
\hline & Specify ENERGY STAR lighting \\
\hline & Use vacancy sensor switches \\
\hline MELs & Use "smart" power strips \\
\hline Meters & See if the local utility is offering smart meters \\
\hline \multicolumn{2}{|c|}{ Combination Projects } \\
\hline \multicolumn{2}{|c|}{ Room Additions Other Than Kitchens, Bedrooms, and Bathrooms } \\
\hline Creating Finished Basement & If incorporating windows, see "Windows" above \\
\hline Air Sealing & Air seal between the foundation wall and framing \\
\hline \multirow[t]{2}{*}{ Insulate } & $\begin{array}{l}\text { Insulate the basement walls (see Ueno and Lstiburek } \\
\text { 2012) }\end{array}$ \\
\hline & If ceiling heights allow, add insulation over the slab \\
\hline Adding a Room & Limit size to meet programmatic needs and no more \\
\hline Air Sealing & Air seal using the air tight drywall approach, see Figure \\
\hline Insulate & Insulate to meet or exceed 2009 IECC; see Figure \\
\hline \multicolumn{2}{|r|}{ Bath Remodel } \\
\hline Hot Water & Add insulation to existing water heater \\
\hline Piping & Insulate hot water piping \\
\hline \multirow{2}{*}{ Water Heater Replacement } & $\begin{array}{l}\text { If replacing the water heater, specify an ENERGY } \\
\text { STAR model, see www.energystar.gov }\end{array}$ \\
\hline & $\begin{array}{l}\text { If considering a heat pump water heater (see Shapiro, C.; } \\
\text { Puttagunta, S.; Owens, D., }\end{array}$ \\
\hline Controls & Set the water heater thermostat at $120^{\circ} \mathrm{F}$ \\
\hline Other Measures & Consider drain water heat recovery \\
\hline Water Conservation & $\begin{array}{l}\text { Use water conserving fixtures, see } \\
\text { www.epa.gov/watersense }\end{array}$ \\
\hline \multirow{2}{*}{ Lighting } & See "Lighting" under Electrical Systems above \\
\hline & Consider tubular skylights for ambient lighting \\
\hline Air Sealing & See "Air Sealing" under Adding a Room, above \\
\hline Insulation & See "Insulation” Under Adding a Room above \\
\hline HVAC Systems & Provide efficient ventilation (see BSC 2004) \\
\hline \multicolumn{2}{|r|}{ Kitchen Remodels } \\
\hline \multirow{2}{*}{ Lighting } & See "Lighting" under Electrical Systems above \\
\hline & Consider tubular skylights for ambient lighting \\
\hline Air Sealing & See "Air Sealing” under Adding a Room, above \\
\hline Insulation & See "Insulation" Under Adding a Room above \\
\hline HVAC Systems & Provide efficient ventilation (see BSC 2004) \\
\hline
\end{tabular}




\section{References}

ASID \& USGBC. (2008). Regreen: Residential Remodeling Guidelines, Second Edition. Washington, DC: ASID and US Green Building Council.

Baechler, M. (2006, October). Buidling America Best Practice Marine Climate. Retrieved November 24, 2011, from Building America: http://apps 1.eere.energy.gov/buildings/publications/pdfs/building_america/38449.pdf

Baechler, M. (2009, May 12). Building America Best Practices - Mixed Humid. Retrieved November 23, 2011, from Building America: http://www1.eere.energy.gov/buildings/building_america/mixed_humid_case_studies.ht $\mathrm{ml}$

Blasnick, M. (2011, December 9). Energy Consultant - REVISE THIS. (C. Liaukus, Interviewer) Blasnik, M. (2011, December 9). Energy Consultant. (C. Liaukus, Interviewer)

De Oreo, W. B., \& Mayer, P. (2001). The End Uses of Hot Water in SIngle Family Homes from Flow Trace Analysis. Retrieved November 23, 2011, from River Network: http://www.rivernetwork.org/resource-library/end-uses-hot-water-single-family-homesflow-trace-analysis

Department of Energy. (2010). Guidelines for Selecting Cool Roofs. Washington: US Department of Energy.

Energy Information Administratin. (1997). Residentail Energy Consumption Survey. Retrieved November 23, 2011, from Energy Infomration Administration: www.eia.gov

ENERGY STAR. (2010, January 4). Residential Windows, Doors and Skylights. Retrieved December 9, 2011, from Energy Star Products: http://www.energystar.gov/ia/partners/prod_development/archives/downloads/windows doors/WindowsDoorsSkylightsProgRequirements7Apr09.pdf

Energy Star. (2011, March 31). National Program Requirements. Retrieved November 24, 2011, from Energy Star:

http://www.energystar.gov/ia/partners/bldrs_lenders_raters/downloads/NationalProgram Requirements_v3.pdf

EPA. (2000). Energy Star AIr Sealing. Washington, D.C., USA.

Green Building Advisor. (2008, December 30). Building Plans for Energy Effiicient Basement Remodeling. Retrieved November 23, 2011, from Green Building Advisor: http://www.greenbuildingadvisor.com/cad/building-plans-energy-efficient-basementremodeling\#WOOD\%20STUD\%20WALL

Green Building Advisor. (2008, December 30). CAD details. Retrieved November 23, 2011, from Green Building Advisor:

http://www.greenbuildingadvisor.com/system/files/sites/default/files/GBA_INDIVIDUA L_PDF_FILES/GBA_PDF_Series-9/9-00800.pdf

Green Building Advisor. (2011, October 21). Green Building Advisor. Retrieved November 23, 2011, from Green Building Advisor: http://greenbuildingadvisor.com/greenbasics/lighting-and-phantom-loads

Green Building Advisor. (2011). How to Build an Insulated Catherdral Ceiling. Retrieved November 20, 2011, from Green Building Advisor:

http://www.greenbuildingadvisor.com/blogs/dept/musings/how-build-insulated-cathedralceiling 
Green Building Advisor. (2011, October 21). Lighting and Phantom Loads. Retrieved November 23, 2011, from Green Building Advisor: http://www.greenbuildingadvisor.com/greenbasics/lighting-and-phantom-loads

Green Building Advisor. (2011, July 24). Lstiburek's Rules for Venting Roofs. Retrieved November 23, 2011, from Green Building Advisor: http://www.greenbuildingadvisor.com/blogs/dept/building-science/lstiburek-s-rulesventing-roofs

Hall, D. (2011, December 2). Contractor. (C. Liaukus, Interviewer)

Hammer, J. (2011, December 9). Contractor. (T. Meierdierck, Interviewer)

Herndon, R., \& Eastment, M. (2006). Development of an Energy Savings Calculation Methodology for Residentail Miscellanouse Electric Loads. Golden, CO: NREL.

Holladay, M. (2010, October 15). Calculating the Minimum Thickness of Rigid Foam Sheathing. Retrieved December 22, 2011, from Musings of an Energy Nerd: http://www.greenbuildingadvisor.com/book/export/html/18223

Institute for Business and Home Safety. (2010). Fortified for Existing Homes. Retrieved December 5, 2011, from Insurance Institute for Business and Home Safety: http://www.disastersafety.org/content/data/file/FEH_HURR_designations.pdf

International Code Council. (2011). 2009 ICC Update. Retrieved November 24, 2011, from International Code Council: http://www.iccsafe.org/gr/content/documents/iecc_toolkit/2009_iecc_update.pdf

ISO, a Verisk Analytics company. (2011). Homeowners and Renters Insurance. Retrieved November 30, 2011, from Insurance Information Institute: http://www.iii.org/facts_statistics/homeowners-and-renters-insurance.html

Joint Center for Housing Studies of Harvard University. (2011). A New Decade of Growth for Remodeling. Cambridge: Joint Center for Housing Studies.

Latiri, W. (2011, December 7). Insurance Agent. (C. Liaukus, Interviewer)

LBNL, BSC. (2005). Best Practices Guide for Residential HVAC Retrofits. Washington, DC: U.S. DOE.

Lstiburek, J., \& Brennan, T. (2004). Read This Before You Design, Build or Renovate. Washington, D.C.: U.S. Department of Housing and Urban Development and the U.S. Department of Energy.

McWilliams, J., \& Walker, I. (2005). Retrofitting Residential HVAC Systems. Home Energy Magazine, 28-33.

Meier, A. (2011, January 3). My Friend the Smart Meter. Home Energy Magazine.

NAHB Research Center. (2001). Drainwater Heat Recovery. Retrieved November 23, 2011, from Toolbase:

http://www.toolbase.org/Techinventory/TechDetails.aspx?ContentDetailID=4050\&Buck etID $=2 \&$ CategoryID $=42$

NAHB Research Center. (2006, September 19). Kitchen Remodeling. Retrieved November 23, 2011, from Toolbase:

http://www.toolbase.org/ToolbaseResources/level4DG.aspx?ContentDetailID=4149\&Bu cketID $=4 \&$ CategoryID $=53$

NAHB Research Center, Southface, ORNL. (2006, September 19). Bathroom Remodeling" Strategies for Energy Efficiency. Retrieved November 24, 2011, from Toolbase: http://www.toolbase.org/PDF/DesignGuides/MDL_\%205_\%20Bathroom.pdf 
National Fire Protection Association. (2011, December). Major Causes of Fire. Retrieved December 15, 2011, from National Fire Protection Association:

http://www.nfpa.org/categoryList.asp?categoryID=952\&URL=Research\%20\&\%20Repor ts/Fire\%20statistics/Major\%20causes\%20of\%20fire\&cookie test $=1$

NREL. (2004). Better Duct Systems for Home Heating and Cooling. Washington: Building America.

Pacific Northwest National Laboratory \& Oak Ridge National Laboratory. (2010). Air Sealing: A Guide for Contractors to Share with Homeowners. Washington D.C.: U. S. Department of Energy.

PATH. (2009, May 29). Energy Efficient Rehab Advisor - Bathroom. Retrieved November 23, 2011, from Energy Efficient Rehab Advisor:

http://rehabadvisor.pathnet.org/audience.asp?Project=7\&BuildingType=1\&UserRole=2\& ClimateType $=1 \&$ BuildingAge $=2$

PATH. (2010). Project Recommendations - Replace Roof. Retrieved November 23, 2011, from Rehab Advisor: http://rehabadvisor.pathnet.org/audience.asp?

PATH. (2011). Rehab Advisor. Retrieved November 22, 2011, from Pathnet: http://rehabadvisor.pathnet.org/audience.asp

PNNL \& ORNL. (2011). HVAC A Guide for Contractors to Share with Homeowners. Washington: US Department of Energy.

PNNL and ORNL. (2006). Building America Best Practice Series: Volume 5. Washington: US Department of Energy.

Rem Brown, P. (2011, December 3). Senior Engineering Manager, IBHS. (C. Liaukus, Interviewer)

Roberts, S., \& Stephenson, R. (2010). Guidelines for Measures \& Strategies - Wall Air Sealing \& Insulation Methods in Existing Homes. Oak Ridge, TN: U.S. Department of Energy Building Technologies Program.

SDG\&E. (2010). Smart Meter Installation Photo Gallery. Retrieved November 23, 2011, from SDG\&E: http://161.209.209.26/smartmeter/gallery.shtml

Sherman, M. (2010, June). Air Tightness: Experiences from US. Berkeley, CA, USA: Lawrence Berkeley National Laboratories.

Sipe, B. (2011). Energy Trust of Oregon 2008 Existing Homes Gas Impact Analysis. Portland: Energy Trust of Oregon.

Southface Energy Institute. (2002, March 5). Airtight Drywall Approach. Atlanta, GA, USA.

SPELLING, J. R. (2011, December 2). President, IBHS. (C. Liaukus, Interviewer)

Straube, J., \& Grin, A. (2010). Building America Speical Research Project High-R Roofs Case Study Analysis. Somerville: Building Science Corporation.

Toolbase. (2010). Energy Efficiency in Remodeling: Roofs and Ceilings. Retrieved November 23, 2011, from Toolbase.org: http://www.toolbase.org/ToolbaseResources/level4DG.aspx?

U. S. Census Bureau. (2011). American Housing Survey for the United States: 2009. Washington, D.C.: U. S. Census Bureau.

U. S. Energy Information Administration. (2011, March 28). Share of energ used y appliances and consumer electronics increases in U.S. homes. Retrieved December 2, 2011, from U.S. Energy Information Administration:

http://www.eia.gov/consumption/residential/reports/electronics.cfm 
U.S.Census. (2011, February 1). Table 2. Alterations Within Residential Structures, Major Replacements, Maintenance, Repairs and Other Work - Owner Occupied Units. Washington, D.C., USA.

Ueno, K., \& Lstibureck, J. (2012). Measure Guideline: Hybrid Foundation Insulation Retrofits. Washington: US Department of Energy.

US DOE EERE. (2011, February 9). Airtight Drywall, and Simple Caulk and Seal for Air Movement Control. Retrieved December 12, 2011, from Energy Savers: http://www.energysavers.gov/your_home/insulation_airsealing/index.cfm/mytopic $=1131$ 0

Vinyl Siding Institute. (2011). Insulated Siding Energy Performance Study. VERIFY: Vinyl Siding Institute.

VonShrader, C. (2011, December 12). EDIT THIS. (C. Liaukus, Interviewer) 
